\title{
EGF and bFGF pre-treatment enhances neural specification and the response to neuronal commitment of MIAMI cells
}

\author{
Gaëtan J.-R. Delcroix ${ }^{\mathrm{a}, \mathrm{b}, 1}$, Kevin M. Curtis ${ }^{\mathrm{c}, \mathrm{d}, 1}$, Paul C. Schiller ${ }^{\mathrm{c}, \mathrm{d}, \mathrm{e}, 2}$, Claudia N. Montero-Menei ${ }^{\mathrm{a}, \mathrm{b}, *, 2}$ \\ a Inserm U646, 10 rue André Boquel, Angers F49100, France \\ ${ }^{\mathrm{b}}$ Univ Angers, UMR-S646, Angers F49100, France \\ c GRECC and Research Service, Veterans Affairs Medical Center, Miami, Florida, USA \\ ${ }^{\mathrm{d}}$ Department of Biochemistry \& Molecular Biology, University of Miami Miller School of Medicine, Miami, Florida, USA \\ e Department of Medicine and Geriatrics and Interdisciplinary Stem Cell Institutes, University of Miami Miller School of Medicine, Miami, Florida, USA
}

\section{A R T I C L E I N F O}

\section{Article history:}

Received 8 March 2010

Received in revised form

28 June 2010

Accepted 12 July 2010

\section{Keywords:}

Mesenchymal stromal cell

Epidermal growth factor

Basic fibroblast growth factor

Neuronal development

Cell therapy

\begin{abstract}
A B S T R A C T
Aims: Multipotent mesenchymal stromal cells raise great interest for regenerative medicine studies. Some MSC subpopulations have the potential to undergo neural differentiation, including marrow isolated adult multilineage inducible (MIAMI) cells, which differentiate into neuron-like cells in a multistep neurotrophin 3-dependent manner. Epidermal and basic fibroblast growth factors are often used in neuronal differentiation protocols for MSCs, but with a limited understanding of their role. In this study, we thoroughly assessed for the first time the capacity of these factors to enhance the neuronal differentiation of MSCs.

Materials and methods: We have characterized MIAMI cell neuronal differentiation program in terms of stem cell molecule expression, cell cycle modifications, acquisition of a neuronal morphology and expression of neural and neuronal molecules in the absence and presence of an EGF-bFGF pretreatment.

Results: EGF-bFGF pre-treatment down-regulated the expression of stemness markers Oct4A, Notch1 and Hes5, whereas neural/neuronal molecules Nestin, Pax6, Ngn2 and the neurotrophin receptor tyrosine kinase 1 and 3 were up-regulated. During differentiation, a sustained Erk phosphorylation in response to NT3 was observed, cells began to exit from the cell cycle and exhibit increased neurite-like extensions. In addition, neuronal $\beta 3$-tubulin and neurofilament expression was increased; an effect mediated via the Erk pathway. A slight pre-oligodendrocyte engagement was noted, and no default neurotransmitter phenotype was observed. Overall, mesodermal markers were unaffected or decreased, while neurogenic/adipogenic PPAR 2 was increased.

Conclusion: EGF and bFGF pre-treatment enhances neural specification and the response to neuronal commitment of MIAMI cells, further increasing their potential use in adult cell therapy of the nervous system.
\end{abstract}

(c) 2010 International Society of Differentiation. Published by Elsevier Ltd. All rights reserved.
Abbreviations: bFGF, basic fibroblast growth factor; BSA, bovine serum albumin; DMEM, Dulbecco's modified Eagle's medium-high glucose; DPBS, Dulbecco's phosphate buffered saline; EGF, epidermal growth factor; FBS, foetal bovine serum; HBSS, Hank's buffered salt solution; ITS, insulin-transferrin-selenium; MIAMI, marrow isolated adult multilineage inducible; MSC, marrow stromal cell; NSC, neural stem cell; NT3, neurotrophin 3; Ntrk, neurotrophic tyrosine kinase receptor; RT-qPCR, real-time quantitative polymerase chain reaction; SD, standard deviation; SEM, scanning electron microscopy; WB, western blot

* Corresponding author at: Inserm U646, 10 rue André Boquel, Angers, France. Tel.: +332417358 94; fax: +33241735853.

E-mail addresses: delcroix.gaetan@gmail.com (G.J.-R. Delcroix), kevinmcurtis@gmail.com (K.M. Curtis), PSchille@med.miami.edu (P.C. Schiller), claudia.montero-menei@univ-angers.fr (C.N. Montero-Menei).

${ }^{1}$ Authors contributed equally to this work.

${ }^{2}$ Both authors contributed equally in the preparation of this manuscript.

\section{Introduction}

Stem cells hold a great promise in regenerative medicine due to their capacity to self-replicate and to produce various differentiated cell types. Nevertheless, the contribution of each stem cell type has to be clearly evaluated in the context of a specific pathology. Among the different sources of stem cells, adult multipotent mesenchymal stromal cells (MSCs) are interesting for cell therapy studies due to their large differentiation potential and their immunoregulatory properties (Delcroix et al., 2010; Le Blanc et al., 2003; Le Blanc, 2003; Maitra et al., 2004; Nasef et al., 2007; Gotherstrom et al., 2004; Horwitz et al., 2005). Moreover, their easy isolation from bone marrow and their selfrenewal capacity may allow autologous grafts to be performed. A number of studies have shown that subpopulations of MSCs 
differentiate into neuron-like cells in vitro, either by genetic manipulation, with the help of co-culture systems or by using different inducer molecules and growth factors (Hermann et al., 2006; Ross and Verfaillie, 2008; Song and Sanchez-Ramos, 2003). In regard to the difficulties in obtaining neural stem cells (NSCs) from adults and the inherent ethical problems linked with their isolation from foetal tissue, the identification of alternative sources of neuron-like cells for cell therapy in the central nervous system is of great importance (Delcroix et al., 2010).

MSCs transplanted in adult rat brains may respond to microenvironmental cues and a fraction of them differentiate into neuron-like cells (Kopen et al., 1999; Zhao et al., 2002; Jendelova et al., 2004). In addition, MSCs that can migrate toward sources of lesions in the brain (Jendelova et al., 2004; Delcroix et al., 2009; Mahmood et al., 2002; Sykova and Jendelova, 2007; Hellmann et al., 2006) may also provide a functional improvement in animal models, either directly or indirectly by their ability to produce various growth factors (Mahmood et al., 2002; Zhang et al., 2005; Chen et al., 2002; Li et al., 2002). Finally, their administration in the central nervous system is feasible and seems to be safe in human subjects (Bang et al., 2005). For all of these reasons, use of MSCs may become a clinically viable technology for cell therapy of the central nervous system that is not hindered by ethical and tissue rejection-related concerns. However, further investigations are still required, particularly with human MSCs, to clearly evaluate their neuronal differentiation potential.

In the present study, we have used a homogenous subpopulation of developmentally immature human MSCs termed marrow isolated adult multilineage inducible (MIAMI) cells. They are small cells with a reduced cytoplasm, which express markers typical of embryonic stem cells and are capable of differentiating in vitro into cell lineages derived from all three germ layers, as previously described (D'Ippolito et al., 2004). Moreover, MIAMI cells, which are isolated and expanded under niche-like conditions, including a low-oxygen tension environment, express the major receptor for hepatocyte growth factor, c-met (D'Ippolito et al., 2004), as well as a number of chemokine and growth factor receptors, that may enhance their migratory potential leading to an improved regenerative potential (Rosova et al., 2008). We recently reported a 3-step neurotrophin 3 (NT3)-dependent differentiation of these cells using a protocol that aims to mimic the differentiation program of NSCs at the molecular level. At the end of this process, $50-60 \%$ of MIAMI cells became immature neuron-like cells with a fraction showing ionic channel activity but no action potential (Tatard et al., 2007). For convenience purpose, in this study, this process will be termed "neuronal differentiation". Based on these results, it appears necessary to improve the neuronal differentiation potential of MIAMI cells, as well as to better understand their behavior and the molecular mechanisms that direct it, in order to optimize their future use in cell therapy studies.

Epidermal growth factor and basic fibroblast growth factor (EGF and bFGF) are powerful mitogens and cell fate drivers for NSCs and neural precursor cells present in the developing and adult central nervous system, as well as for ES cell-derived neural precursors (Bithell et al., 2008; Tsai and Kim, 2005; Temple, 2001; Caldwell et al., 2004; Guan et al., 2001; Reynolds et al., 1992). Interestingly, these factors may also permit the long-term proliferation of human mesencephalic precursors expanded under hypoxia (Schwarz, 2007), while bFGF may contribute to maintain the neurogenic niche in vivo (Mudo et al., 2009). It has been shown that MSCs, including MIAMI cells, may already express certain neural-related genes (Tondreau et al., 2004; Woodbury et al., 2002), and it was therefore assumed that an EGF-bFGF exposure may further improve their in vitro neuronal differentiation. In MSCs, the expression of Nestin, a marker expressed by
NSCs (Gilyarov, 2008), was up-regulated after EGF and bFGF exposure under adherent (Song et al., 2007) or non-adherent conditions prior to in vitro neurogenesis (Hermann et al., 2004; Kim et al., 2006; Yang et al., 2008). Furthermore, recent studies described the differentiation of MSCs, after a first-step treatment with EGF-bFGF, into dopamine-producing cells leading to a functional improvement in a rat model of Parkinson's disease (Barzilay et al., 2008; Levy et al., 2008). However, a precise characterization of the impact of an EGF-bFGF pre-treatment, prior to MSC neuronal differentiation, by comparing to non-pretreated cells and extensively analyzing several neuronal molecules is still lacking (Song et al., 2007; Hermann et al., 2004; Kim et al., 2006; Yang et al., 2008; Long et al., 2005). It is therefore important to thoroughly assess the benefits of using EGF-bFGF pre-treatment prior to the induction of MSCs toward a neuronal lineage.

In this study, we first sought to assess the potential benefits of an EGF-bFGF pre-treatment in terms of neuronal lineage specification of MIAMI cells to further improve their neuronal differentiation in vitro. In addition, the effects of the EGF-bFGF pre-treatment were characterized and compared on MIAMI cells harvested from vertebral bodies or from iliac crest of living donors. As NT3 is essential for MIAMI cells' neuronal-like differentiation, we also studied the effect of EGF-bFGF on the response of MIAMI cells to NT3, by evaluating the expression of the NT3 receptors and Erk phosphorylation involved in this transduction pathway. Neuronal differentiation involves the reduction of cell proliferation leading to post-mitotic cells, a process accompanied by a loss of stem cell molecules together with the acquisition of a neuronal morphology and the expression of neural and neuronal molecules. Therefore, we further analysed the behavior of MIAMI cells, with or without pre-treatment, along the differentiation protocol in terms of neuronal morphology, proliferation, apoptosis and molecular expression pattern.

\section{Materials and methods}

\subsection{Bone marrow harvesting, selection and expansion of MIAMI cells}

Whole bone marrow was obtained from vertebral bodies (T1-L5) of a 3-year-old male cadaveric donor who died of fatal traumatic injury (MIAMI \#519) (D'Ippolito et al., 2004) or from iliac crest of a 20-year-old male living donor (Lonza Walkersville, Maryland; MIAMI \#3515), following guidelines for informed consent set by the University of Miami School of Medicine Committee on the Use of Human Subjects in Research. As previously described (D'Ippolito et al., 2004), isolated whole bone marrow cells were plated at a constant density of $10^{5} \mathrm{cells} / \mathrm{cm}^{2}$ in DMEM-low glucose media, containing $5 \%$ foetal bovine serum (FBS) (Hyclone, South Logan, Utah) and antibiotics (AB) (100 U/mL penicillin, $0.1 \mathrm{mg} / \mathrm{mL}$ streptomycin, $0.25 \mu \mathrm{g} / \mathrm{mL}$ amphotericin $\mathrm{B}$ ) (Sigma, St Quentin Fallavier, France) on a fibronectin (Sigma) substrate. Whole bone marrow cells, containing adherent and non-adherent cells, were incubated at $37^{\circ} \mathrm{C}$ under hypoxic conditions $\left(3 \% \mathrm{O}_{2}, 5 \% \mathrm{CO}_{2}\right.$ and $\left.92 \% \mathrm{~N}_{2}\right)$. Seven days later, half of the culture medium was replaced. Fourteen days after the initial plating, the non-adherent cells were removed. Pooled colonies of adherent cells were carefully rinsed and plated at low density for expansion $\left(100\right.$ cells $\left./ \mathrm{cm}^{2}\right)$ on $1.25 \mathrm{ng} / \mathrm{cm}^{2}$ fibronectin. Cells were expanded in DMEM-low glucose (Gibco, Cergy Pontoise, France), $3 \%$ FBS and $\mathrm{AB}\left(40 \mathrm{~mL} / 175 \mathrm{~cm}^{2}\right.$ flask) under hypoxic conditions. Cells were fed every $2-3$ days by changing half the medium and split every 5 days, keeping $1 / 4$ of old medium. Presented results were obtained with vertebral bodies-isolated MIAMI cells, unless otherwise stated. 


\subsection{Neural stem cells}

For use as positive controls, foetal neuroepithelial progenitor cells were kindly provided by Dr. Micheline McCarthy (Department of Neurology, University of Miami Miller School of Medicine) and cultured as previously described (Tatard et al., 2007).

\subsection{EGF-bFGF pre-treatment}

A 10-day EGF and bFGF pre-treatment was performed using either a low dose $(5 \mathrm{ng} / \mathrm{mL})$ or a high dose $(20-50 \mathrm{ng} / \mathrm{mL})$ of both EGF and bFGF (R\&D Systems Europe, Lille, France) supplemented with $5 \mu \mathrm{g} / \mathrm{mL}$ heparin (Sigma) and a lipid mixture (working concentration of $510 \mathrm{nM}$ lipoic, $70 \mathrm{nM}$ linolenic and $150 \mathrm{nM}$ linoleic acid, all from Sigma). Unless otherwise stated, presented results were obtained with a dose of $20 \mathrm{ng} / \mathrm{mL}$ EGF-bFGF. To investigate the NT3 response of pre-treated cells, we checked the neurotrophin receptor expression in response to 0,50 and a higher dose $(100 \mathrm{ng} / \mathrm{mL})$ of EGF-bFGF. As we already observed an effect at the intermediary dose $(50 \mathrm{ng} / \mathrm{mL})$, we continued with this dose for the detection of Erk/pErk. Briefly, cells were treated with NT3 (30 ng/mL) for 5, 10 and $15 \mathrm{~min}$ following a serum deprivation phase of $24 \mathrm{~h}$ prior processing for western blotting. Erk inhibitor U0126 (Sigma) was also used, at a concentration of $10 \mu \mathrm{M}, 1 \mathrm{~h}$ prior to the addition of NT3 to observe the changes in mRNAs expression after neuronal induction (step 2, see below).

\subsection{MIAMI cells' neuronal-like differentiation}

This three-step differentiation process was described in greater detail elsewhere (Tatard et al., 2007) and is depicted in Fig. 3A. Non-pre-treated or EGF-bFGF pre-treated MIAMI cells passages 5-9 were seeded at $3000-4000$ cells $/ \mathrm{cm}^{2}$ on a $2 \mu \mathrm{g} / \mathrm{cm}^{2}$ fibronestin-coated surface in DMEM F12 (GIBCO) supplemented with $20 \% \mathrm{FBS}, 10 \mathrm{ng} / \mathrm{mL}$ bFGF (for the non-pre-treated), antibiotics and cultured for $24 \mathrm{~h}$ (Neural specification, step 1). At the end of the neural specification treatment, cells were washed and neuronal commitment (step 2) was induced by exposing the cells to $30 \mathrm{ng} / \mathrm{ml} \mathrm{NT3} \mathrm{(R \& D} \mathrm{Systems)} \mathrm{in} \mathrm{the} \mathrm{presence} \mathrm{of} 1 \mathrm{mM}$ $\beta$-mercaptoethanol (Sigma), for 2 days. Neuronal differentiation (step 3) was induced by rinsing and then exposing the cells to $100 \mu \mathrm{M}$ butylated hydroxyanisole, $25 \mathrm{mM} \mathrm{KCl,} 2 \mathrm{mM}$ valproic acid, $4 \mu \mathrm{M}$ forskolin, $1 \mu \mathrm{M}$ hydrocortisone, $5 \mu \mathrm{M}$ insulin, $5 \mathrm{mM}$ Hepes, $10 \mu \mathrm{M}$ rolipram (all from Sigma), $30 \mathrm{ng} / \mathrm{mL}$ NT3, $10 \mathrm{ng} / \mathrm{mL}$ NGF (R\&D Systems), and $30 \mathrm{ng} / \mathrm{mL}$ BDNF (R\&D Systems) for 3 days, unless otherwise stated. Use of insulin-transferrinselenium and lipid media supplement (ITS+3) (Sigma) was also tested during the differentiation protocol (working concentrations of $10 \mu \mathrm{g} / \mathrm{ml}$ insulin, $5.5 \mu \mathrm{g} / \mathrm{ml}$ apotransferrin, $5 \mathrm{ng} / \mathrm{ml}$ sodium selenite, $4.7 \mathrm{ng} / \mathrm{ml}$ linoleic acid, $4.7 \mathrm{ng} / \mathrm{ml}$ oleic acid and $0.5 \mu \mathrm{g} / \mathrm{ml}$ BSA). Neuronal differentiation was performed at ambient atmospheric oxygen $\left(21 \% \mathrm{pO}_{2}\right)$.

\subsection{Intracellular labeling and flow cytometry}

MIAMI cells were washed with DMEM-low glucose and detached with $10 \mathrm{~mL}$ Versene (Lonza) for $20 \mathrm{~min}$ at $37^{\circ} \mathrm{C}$. After pelleting, cells were washed with DPBS and fixation was performed in $0.25 \%$ formaldehyde (Sigma) for $30-60 \mathrm{~min}$ at $4{ }^{\circ} \mathrm{C}$. After fixation, cells were pelleted, permeabilized with $0.5 \%$ Tween 20 (Sigma) in DPBS for $15 \mathrm{~min}$ at $37{ }^{\circ} \mathrm{C}$ and then rinsed with DPBS, $2 \%$ FBS, $0.02 \%$ azide, $0.2 \%$ Tween 20 . Incubation with mouse antiNestin antibody (1:15, clone 3k1, \#ab6320, Abcam, Paris, France) or IgG1k isotypic antibody (\#557273, BD Biosciences, Le Pont De
Claix, France) in DPBS, 2\% FBS, 0.02\% azide was made for $1 \mathrm{~h}$ at $4{ }^{\circ} \mathrm{C}$. After washing, FITC-conjugated anti-mouse antibody (1:50, \#F0479, Dako, Trappes, France) was added for $30 \mathrm{~min}$ at $4{ }^{\circ} \mathrm{C}$. The cells were washed and finally fixed in DPBS, azide, $0.7 \%$ formaldehyde. Fluorescence signals were acquired with a FACScalibur flow cytometer (BD Biosciences) and data analysed with the Cellquest software (BD Biosciences). The background level was estimated using the fluorescence signal of the isotypic control. Human NSCs were used as a positive control.

\subsection{Primer design and validation}

The following experimental details were performed following the guidelines of the SCCAN core facility ("Service Commun de Cytométrie et d'Analyse Nucléotidique", Angers, France). Human sequences were determined using Pubmed nucleotide search (www.ncbi.nlm.nih.gov) and Ensembl (www.ensembl.org) websites. The online freeware Primer3 (http://frodo.wi.mit.edu/ cgi-bin/primer3/primer3_www.cgi) was used for primer modelling, clustalw (www.ebi.ac.uk) to align nucleotidic sequences and nucleotide blast (www.ncbi.nlm.nih.gov) to confirm the specificity of the defined primer sequences. When possible, pairs of primers were designed across intron-spanning regions to avoid genomic DNA contamination. Sense and antisense desalted primer pairs (Eurogentec, Angers, France or Origen, USA) were mixed in RNAse free water at a final concentration of $5 \mu \mathrm{M}$ and validated using cDNA from expanding or differentiated MIAMI cells, expanding or differentiated foetal neuroepithelial cells and commercial qPCR Human Reference cDNA (Clontech, Takara bio, Saint-Germain-en-Laye, France). The melting peak of the amplicon had to be narrow and unique, and its size and specificity were confirmed by electrophoresis. Finally, a serial dilution of the PCR product was re-amplified to draw a linear curve $\mathrm{Ct}=f$ (Quantity). The efficiency of the primer was calculated from the slope of the linear curve: $E=\left[10^{(-1 / \text { slope })}-1\right] \times 100$. Only primer pairs with an efficiency greater than $80 \%$ were validated for use (Table 1 ).

\section{7. $R T-q P C R$}

During expansion and at the various steps of the differentiation protocol, MIAMI cells were detached using trypsin-EDTA (Sigma) and washed in DPBS. Following the manufacturer's guidelines, cells were lysed in a $1 \% \beta$-mercaptoethanol containing buffer and RNA extracted following a treatment by DNAse to remove any traces of genomic DNA (Total RNA isolation Nucleospin ${ }^{\circledR}$ RNA II, Macherey Nagel, Hoerdt, France). First strand cDNA synthesis was performed with a Ready-To-Go You-Prime First-Strand Beads ${ }^{\circledR}$ kit in combination with random hexamers (Amersham Biosciences, Orsay, France) using $1 \mu \mathrm{g}$ RNA according to the manufacturer's guidelines. Following first-strand cDNA synthesis, cDNAs were purified (Qiaquick PCR purification kit, Qiagen, Courtaboeuf, France) and eluted in $50 \mu \mathrm{L}$ RNAse free water (Gibco). Five microliters of cDNA (1:20) was mixed with iQ SYBR Green Supermix (Biorad) and primer mix $(0.2 \mu \mathrm{M})$ in a final volume of $15 \mu \mathrm{L}$. Amplification was carried out on a Chromo 4 thermocycler (Biorad) with a first denaturation step at $95{ }^{\circ} \mathrm{C}$ for $3 \mathrm{~min}$ and 40 cycles of $95{ }^{\circ} \mathrm{C}$ for $10 \mathrm{~s}, 55^{\circ} \mathrm{C}$ for $15 \mathrm{~s}$ and $72{ }^{\circ} \mathrm{C}$ for $15 \mathrm{~s}$. After amplification, a melting curve of the products determined the specificity of the primers for the targeted genes. A mean cycle threshold value $(\mathrm{Ct})$ was obtained from 2 measurements for each cDNA. Several housekeeping genes, Glyceraldehyde-3-phosphate dehydrogenase (Gapdh, NM_002046), Hypoxanthine phosphoribosyltransferase 1 (Hprt1, NM_000194), Beta actin (Actb, NM_001101), 30S ribosomal protein S18 (Rps18, NM_001093779) and Heat shock $90 \mathrm{kDa}$ 
Table 1

Human specific primer sequences.

\begin{tabular}{|c|c|c|c|c|}
\hline Gene & Full name & NM accession number & Sequences & Amplicon \\
\hline AChE & Acetylcholinesterase & NM_015831-NM_000665 & 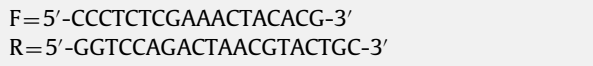 & 163 \\
\hline$\beta 3-T u b u l i n$ & Homo sapiens tubulin, beta 3 & NM_006086 & $\begin{array}{l}\mathrm{F}=5^{\prime}-\text { CCAGTATGAGGGAGATCG-3' } \\
\mathrm{R}=5^{\prime}-\text { CACGTACTTGTGAGAAGAGG }-3^{\prime}\end{array}$ & 185 \\
\hline CCND1 & Cyclin D1 & NM_053056 & $\begin{array}{l}\mathrm{F}=5^{\prime}-\mathrm{CTCTCCAAAATGCCAGAG-3'} \\
\mathrm{R}=5^{\prime}-\text { GATGGACAGGAAGTTGTTGG-3' }\end{array}$ & 186 \\
\hline ChAT & Choline acetyltransferase & $\begin{array}{l}\text { NM_020549-NM_020984- } \\
\text { NM_020985-NM_020986 }\end{array}$ & $\begin{array}{l}\text { hs_chat_1_sg quantitect primer assay, ref qt00029624, } \\
\text { qiagen }\end{array}$ & Unknown \\
\hline$D A T$ & Dopamine transporter & NM_001044 & 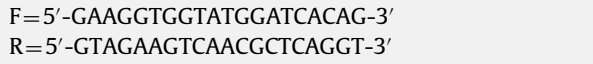 & 121 \\
\hline EGFR & EGF receptor & NM_005228 & $\begin{array}{l}\mathrm{F}=5^{\prime}-\mathrm{CAGCCACCCATATGTACC}-3^{\prime} \\
\mathrm{R}=5^{\prime}-\mathrm{TGGAGTCTGTAGGACTTGG}-3^{\prime}\end{array}$ & 184 \\
\hline FGFR1 & FGF receptor 1 & $\begin{array}{l}\text { NM_015850-NM_023105- } \\
\text { NM_023106-NM_023110- } \\
\text { NM_023111 }\end{array}$ & $\mathrm{F}=5^{\prime}-\mathrm{GGTAACTCTATCGGACTCTCC-3'}$ & 198 \\
\hline & & & $\mathrm{R}=5^{\prime}$-GTGGAAGTCACTCTTCTTGG-3' & \\
\hline GAD 25/67 & Glutamate decarboxylase & NM_000817-NM_013445 & 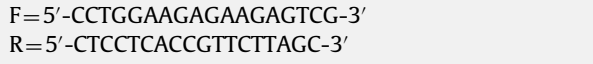 & 166 \\
\hline GalC & Galactosylceramidase & NM_000153-NM_001037525 & $\begin{array}{l}\mathrm{F}=5^{\prime}-\mathrm{GTTGCCTTATGGGAGATG}-3^{\prime} \\
\mathrm{R}=5^{\prime}-\text { AAGCCATCAGTCAGAGGCTAC-3' }\end{array}$ & 183 \\
\hline GFAP & Glial fibrillary acidic protein & NM_002055 & 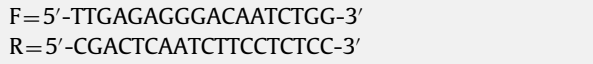 & 161 \\
\hline HES5* & Hairy and enhancer of split 5 & NM_001010926 & $\begin{array}{l}\mathrm{F}=5^{\prime}-\text { AGCCCCAAAGAGAAAAACCGA-3' } \\
\mathrm{R}=5^{\prime}-\mathrm{GCTGTGCTTCAGGTAGCTGAC}-3^{\prime}\end{array}$ & 183 \\
\hline$L p L^{*}$ & Lipoprotein lipase & NM_000237 & $\begin{array}{l}\mathrm{F}=5^{\prime} \text {-ACAAGAGAGAACCAGACTCCAA- } 3^{\prime} \\
\mathrm{R}=5^{\prime} \text {-AGGGTAGTTAAACTCCTCCTCC- } 3^{\prime}\end{array}$ & 149 \\
\hline$M A P 1 b$ & Microtubule-associated protein $1 b$ & NM_005909 & 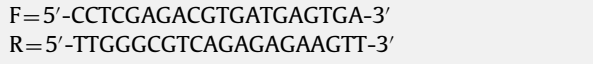 & 437 \\
\hline Msi1 & Homo sapiens musashi homolog 1 & NM_002442 & 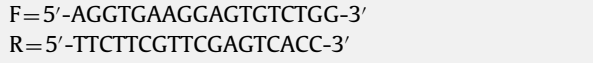 & 196 \\
\hline Nes & Nestin & NM_006617 & $\begin{array}{l}\mathrm{F}=5^{\prime}-\text { AGAAACAGGGCCTACAGAG-3' } \\
\mathrm{R}=5^{\prime} \text {-AAAGCTGAGGGAAGTCTTG-3' }\end{array}$ & 170 \\
\hline$N F L^{*}$ & Neurofilament, light polypeptide & NM_006158 & $\begin{array}{l}\mathrm{F}=5^{\prime}-\text { ATGAGTTCCTTCAGCTACGAGC }-3^{\prime} \\
\mathrm{R}=5^{\prime}-\mathrm{GGGCATCAACGATCCAGAGC}-3^{\prime}\end{array}$ & 198 \\
\hline NFM & Neurofilament, medium polypeptide & NM_005382 & 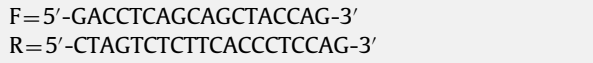 & 170 \\
\hline$N F H^{*}$ & Neurofilament, heavy polypeptide & NM_021076 & 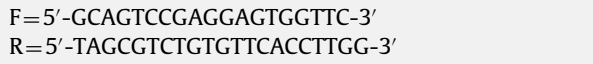 & 71 \\
\hline $\operatorname{Ngn} 2^{*}$ & Neurogenin 2 & NM_024019 & $\begin{array}{l}\mathrm{F}=5^{\prime}-\text { CGCATCAAGAAGACCCGTAG-3' } \\
\mathrm{R}=5^{\prime}-\mathrm{GTGAGTGCCCAGATGTAGTTGTG-3'}\end{array}$ & 173 \\
\hline Notch1 & Notch homolog 1, translocation-associated & NM_017617 & $\begin{array}{l}\mathrm{F}=5^{\prime}-\mathrm{GACCTCATCAACTCACACG}-3^{\prime} \\
\mathrm{R}=5^{\prime}-\text { AGAAACAGGGGTGTCTCC }-3^{\prime}\end{array}$ & 198 \\
\hline $\begin{array}{l}\text { Nurr1 } \\
\quad(N R 4 A 2)^{*}\end{array}$ & $\begin{array}{l}\text { nuclear receptor subfamily } 4 \text {, group } A \text {, } \\
\text { member } 2\end{array}$ & NM_006186 & $\begin{array}{l}\mathrm{F}=5^{\prime}-\text { TTGCCAGATGCGCTTCGACG }-3^{\prime} \\
\mathrm{R}=5^{\prime}-\text { CCAACAGCCAGGCACTTCTG }-3^{\prime}\end{array}$ & 414 \\
\hline Oct4A & Pou class 5 homeobox 1 & NM_002701 & 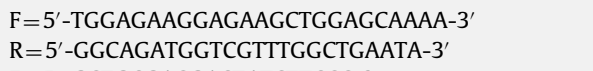 & 186 \\
\hline Olig2* & Oligodendrocyte lineage transcription factor 2 & NM_005806 & 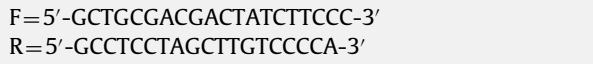 & 244 \\
\hline Pax6* $^{*}$ & Paired box 6 & $\begin{array}{l}\text { NM_000280-NM_001604- } \\
\text { NM_001127612 }\end{array}$ & $\begin{array}{l}\mathrm{F}=5^{\prime} \text {-AGGTATTACGAGACTGGCTCC }-3^{\prime} \\
\mathrm{R}=5^{\prime} \text {-TCCCGCTTATACTGGGCTATTT }-3^{\prime}\end{array}$ & 104 \\
\hline p21 & Cyclin-dependent kinase inhibitor $1 \mathrm{~A}$ & NM_000389-NM_078467 & 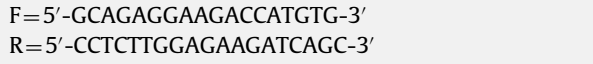 & 171 \\
\hline PPAR gamma & $\begin{array}{l}\text { Peroxisome proliferator-activated receptor } \\
\text { gamma }\end{array}$ & $\begin{array}{l}\text { NM_138712-NM_015869- } \\
\text { NM_138711-NM_005037 }\end{array}$ & $\begin{array}{l}\mathrm{F}=5^{\prime}-\text { AACAGATCCAGTGGTTGC }-3^{\prime} \\
\mathrm{R}=5^{\prime}-\text { CTCCACAGACACGACATTC }-3^{\prime}\end{array}$ & 176 \\
\hline Runx2* & Runt-related transcription factor 2 & NM_001024630-NM_004348 & 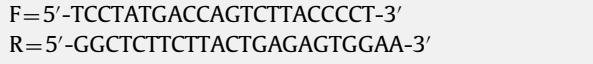 & 190 \\
\hline Sox9* & Sex determining region $Y$-box 9 & NM_000346 & 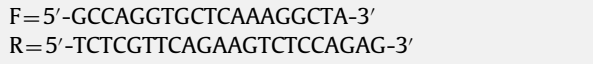 & 213 \\
\hline $\begin{array}{l}\text { Sp7 } \\
\qquad(\text { Osterix })^{*}\end{array}$ & Sp7 transcription factor & NM_152860 & $\begin{array}{l}\mathrm{F}=5^{\prime}-\text { CCCAGGCAACACTCCTACTC- } 3^{\prime} \\
\mathrm{R}=5^{\prime}-\text { GGCTGGATTAAGGGGAGCAAA-3' }\end{array}$ & 175 \\
\hline$T H^{*}$ & Tyrosine hydroxylase & $\begin{array}{l}\text { NM_199292-NM_000360- } \\
\text { NM_199293 }\end{array}$ & $\begin{array}{l}\mathrm{R}=5^{\prime}-\text { GCAATCAGCTTCCTGCGCTG-3' } \\
\mathrm{F}=5^{\prime}-\text { CACCATCTAGAGACCCGGCC-3' }\end{array}$ & 290 \\
\hline
\end{tabular}

Primers with an “*” were obtained from Origen, USA and experiments with these primers performed in Miami's facilities.

protein 1 beta (Hspcb, NM_007355) were tested for normalization. The GeNorm ${ }^{\mathrm{TM}}$ freeware (http://medgen.ugent.be/ $\sim$ jvdesomp/genorm/) was used to determine that Gapdh, Hprt1 and Hspcb were the three most stable housekeeping genes. The relative transcript quantity $(Q)$ was determined by the delta $\mathrm{CT}$ method $Q=E^{(\mathrm{Ct} \text { min in all the samples tested }-\mathrm{Ct} \text { of the sample) }}$, where $E$ is 
related to the primer efficiency $(E=2$ if the primer efficiency $=100 \%$ ). Relative quantities $(Q)$ were normalized using the multiple normalization method described in Vandesompele et al., (2002). $Q$ normalized $=Q /$ (geometric mean of the three most stable housekeeping genes $Q$ ). In the University of Miami's facilities, normalization was performed in a similar manner with two housekeeping genes, Eukaryotic translational elongation factor 1 alpha (Ef1a, NM_001402) and Ribosomal protein L13a (RpL13a, NM_012423). On figures, results are expressed as a percentage of change in the expression of the mRNA relative to the expression in expanding MIAMI cells \pm average deviation (\% change mRNA $\mathrm{X}=\left[\left(Q_{x}-Q_{\text {expanding MIAMI cells }}\right) / Q_{\text {expanding MIAMI }}\right.$ cells $] \times 100)$.

\subsection{Western blotting}

Cell protein extracts were separated into Triton X-100 soluble and insoluble lysates. Protease inhibitor cocktail (Sigma) was added to both lysis buffers directly prior to use. The cell pellet was resuspended in buffer $\mathrm{A}$ [500 mM Tris- $\mathrm{HCl}$ pH 6.8, 50 mM EGTA, $1 \mathrm{M} \mathrm{KCl}, 10 \%$ Triton X-100 (all from Sigma)], triturated, vortexed and centrifugated at $13,000 \mathrm{~g}$ for $20 \mathrm{~min}$ to pellet the Triton $\mathrm{X}-100$ insoluble pellet. Buffer A containing the supernatant Triton X-100 soluble fraction was stored at $-80^{\circ} \mathrm{C}$. The Triton $\mathrm{X}-100$ insoluble pellet was washed twice with buffer B [500 mM Tris- $\mathrm{HCl}$ pH 6.8, $50 \mathrm{mM}$ EGTA, $850 \mathrm{mM}$ sucrose, $10 \%$ Triton X-100 (all from Sigma)] then centrifugated at $13,000 \mathrm{~g}$ for $20 \mathrm{~min}$. Buffer B was aspirated from the Triton $\mathrm{X}-100$ insoluble pellet and the pellet was reconstituted in Laemmli buffer [10\% SDS, $500 \mathrm{mM}$ Tris-HCl $\mathrm{pH}$ 6.8 , 4\% glycerol, 1\% ß-ME, bromophenol blue (all from Sigma)], boiled for $5 \mathrm{~min}$ and stored at $-80{ }^{\circ} \mathrm{C}$. Sample protein concentration was determined using the BCA protein assay (Pierce, Rockford, IL, USA). Primary antibodies included rabbit anti-Ntrk1 (1:2000, polyclonal, \#sc-118, Santa Cruz Biotechnology, Santa Cruz, CA, USA), mouse anti-Ntrk3 (1:500, clone 75213, \#MAB3731, R\&D Systems), mouse anti-pErk p44/42 (1:2000, \#9106S, Cell Signaling Technology, Danvers, MA, USA), mouse anti-Erk p44/42 (1:2000, \#9107, Cell Signaling Technology), goat anti-pTau (Ser396) (1:500, polyclonal, \#sc-12414, Santa Cruz Biotechnology) and mouse anti-Tau (1:500, monoclonal, \#sc-32274, Santa Cruz Biotechnology). Secondary antibodies used were sheep anti-mouse IgG-horseradish peroxidase (HRP) (1:2000, GE Healthcare, USA), goat anti-rabbit IgG-HRP and bovine anti-goat IgG-HRP (1:1000, both from Santa Cruz Biotechnology) depending on the primary antibody. The $50 \mu \mathrm{g}$ protein extracts were electrophoresed on $6 \%$ or $10 \%$ gels and transferred onto Immobilon-P $0.2 \mu \mathrm{M}$ membranes (Millipore). Membranes were blocked with 5\% BSA-DPBS for $1 \mathrm{~h}$ then incubated with primary antibody in 5\% BSA-DPBS. Secondary antibodies were diluted in DPBS alone and incubated on the membrane for $45 \mathrm{~min}$. Membranes were developed with ECL Plus Western Blot Detection System (GE Healthcare) and an AFP Imaging Mini-Medical Services Auto developer. Image analysis was completed using Image (http://rsbweb.nih.gov/ij/). Coomasie blue staining of the blot was used to control the total amount of proteins loaded.

\subsection{Caspase 3 assay}

MIAMI cells were plated in $1.9 \mathrm{~cm}^{2}$ fibronectin-coated wells and Caspase 3 activity was assessed following the Caspase 3 assay kit (Sigma) guidelines. Briefly, positive controls were induced by exposing the cells to Staurosporine $(1 \mu \mathrm{g} / \mathrm{mL}$, Sigma) for $4 \mathrm{~h}$ at $37^{\circ} \mathrm{C}$. After apoptotic induction of the positive controls, cell culture medium of every well was replaced by assay buffer and frozen at $-80^{\circ} \mathrm{C}$. After thawing, Caspase 3 substrate
(Ac-DEVD-AMC) was added and the solutions transferred to black plates (Greiner bio-one, Courtaboeuf, France). Fluorescence was read in a kinetic mode for $1 \mathrm{~h}$ at room temperature using a Fluoroskan Ascent FL microplate reader (Thermo Fisher scientific, Illkirch, France) with excitation/emission wavelengths of $355-460 \mathrm{~nm}$, respectively. Caspase 3 activity was read from a 7-amino-4-methylcoumarin standard curve. Caspase 3 specificity of the fluorescent signal was assessed with the Caspase 3 inhibitor (Ac-DEVD-CHO). Every condition was performed in triplicate.

\subsection{Immunocytofluorescence}

Uninduced and induced cells at the end of step 2 (neuronal commitment) and step 3 (neuronal differentiation) of neuronal induction were used for Nestin, $\beta 3$-Tubulin and NFM immunocytofluorescence. After washing the slides three times with DPBS, cells were fixed with $4 \%$ paraformaldehyde at $4{ }^{\circ} \mathrm{C}$ for $15 \mathrm{~min}$ and then permeabilized with $0.2 \%$ Triton X-100 (Sigma) for 5 min. Slides were blocked with DPBS, $10 \%$ normal goat serum (Sigma), $4 \%$ bovine serum albumin (BSA) (Sigma) at room temperature for $45 \mathrm{~min}$. After washing, slides were incubated overnight at $4{ }^{\circ} \mathrm{C}$ with anti-NFM (1:50, clone NN18, \#N5264, Sigma), anti- $\beta 3$ Tubulin (1:1000, clone SDL.3D10, \#T8660, Sigma) or anti-Nestin (1:200, clone 10C2, \#MAB5326, Chemicon, St Quentin en Yvelines, France) antibodies in DPBS, 4\% BSA, 0.2\% Triton X-100. Isotypic controls were made with IgG1k (clone MOPC-31C, \#557273, BD Biosciences) and IgG2bk (clone 27-35, \#555740, BD Biosciences). After rinsing, the cells were incubated with the secondary biotinylated anti-mouse antibody (1:200, Abcys) in DPBS, 4\% BSA, $0.2 \%$ Triton $\mathrm{X}-100$ for $1 \mathrm{~h}$. Finally, after rinsing again and following incubation with streptavidin-FITC (1:50, \#F0422, Dako) in DPBS for $40 \mathrm{~min}$, the slides were mounted (Dako) and observed with a fluorescence microscope (Axioscop, Carl Zeiss, Le Pecq, France), a CoolSnap ES camera (Photometrics, Tucson, AZ, USA) and Metavue software (Roper Scientific, Evry, France).

\subsection{Scanning electron microscopy (SEM)}

Cells were cultivated on glass slides, fixed with $2 \%$ glutaraldehyde (Sigma) and post-fixed with $2 \%$ osmium tetroxide. Cells were then dehydrated with increasing concentrations of ethanol (Sigma) and transferred into acetone (Sigma) prior to drying in a Bal-Tec CPD 030 critical point dryer (Bal-Tec, Liechtenstein). Samples were finally coated with carbon and examined with a Jeol 6301F scanning electron microscope (Jeol, Croissy sur Seine, France) at $11 \mathrm{kV}$ for backscattered images.

\subsection{Oil red staining}

Oil red o (Sigma) solution (0.36\%) was made in $60 \%$ isopropanol (Sigma) and agitated overnight before filtration. Medium was removed and cells fixed with $4 \%$ paraformaldehyde during 30-40 min. Cells were washed with DPBS and water before staining with oil red solution for $50 \mathrm{~min}$. Samples were finally washed with water and observed with a bright field microscope (Axiovert 40 CFL, Carl Zeiss).

\subsection{Statistical analysis}

Data are presented as the mean value of three independent experiments \pm standard deviation (SD), unless otherwise stated. Significant differences between samples were determined using a Student's $t$-test modified for small samples with $t_{0}^{\prime}=\left(m_{1}-m_{2}\right) / \sqrt{ }\left(s_{1}^{2} / n_{1}+s_{1}^{2} / n_{2}\right)$. Differences were considered sig-

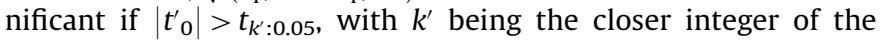


calculated $\quad k=\left(s_{1}^{2} / n_{1}+s_{1}^{2} / n_{2}\right)^{2} /\left[\left(1 /\left(n_{1}-1\right)\left(s_{1}^{2} / n_{1}\right)^{2}\right)+\left(1 /\left(n_{2}-1\right)\right.\right.$ $\left.\left.\left(s_{1}^{2} / n_{2}\right)^{2}\right)\right]$. Kruskal-Wallis test was used for multiple comparisons. Threshold $P$-value was set to 0.05 .

\section{Results}

\subsection{Direct effects of MIAMI cell exposure to EGF-bFGF}

EGF and bFGF receptors, EGFR and FGFR1, respectively, were highly expressed when assessed by RT-qPCR, suggesting that MIAMI cells may respond to the stimuli induced by these factors. The lipid mixture alone had no effects on the cells. In the following section, we first focus on the direct effects induced in MIAMI cells by an EGF-bFGF exposure.

\subsection{Expression of stem and early neural-related genes after EGF-bFGF treatment}

RT-qPCR demonstrated that expanding MIAMI cells expressed the stemness marker Oct4A, which was down-regulated after treatment with EGF-bFGF for 10 days $(2.5 \pm 0.5$-fold decrease). MIAMI cells also expressed a panel of early neural-related genes,

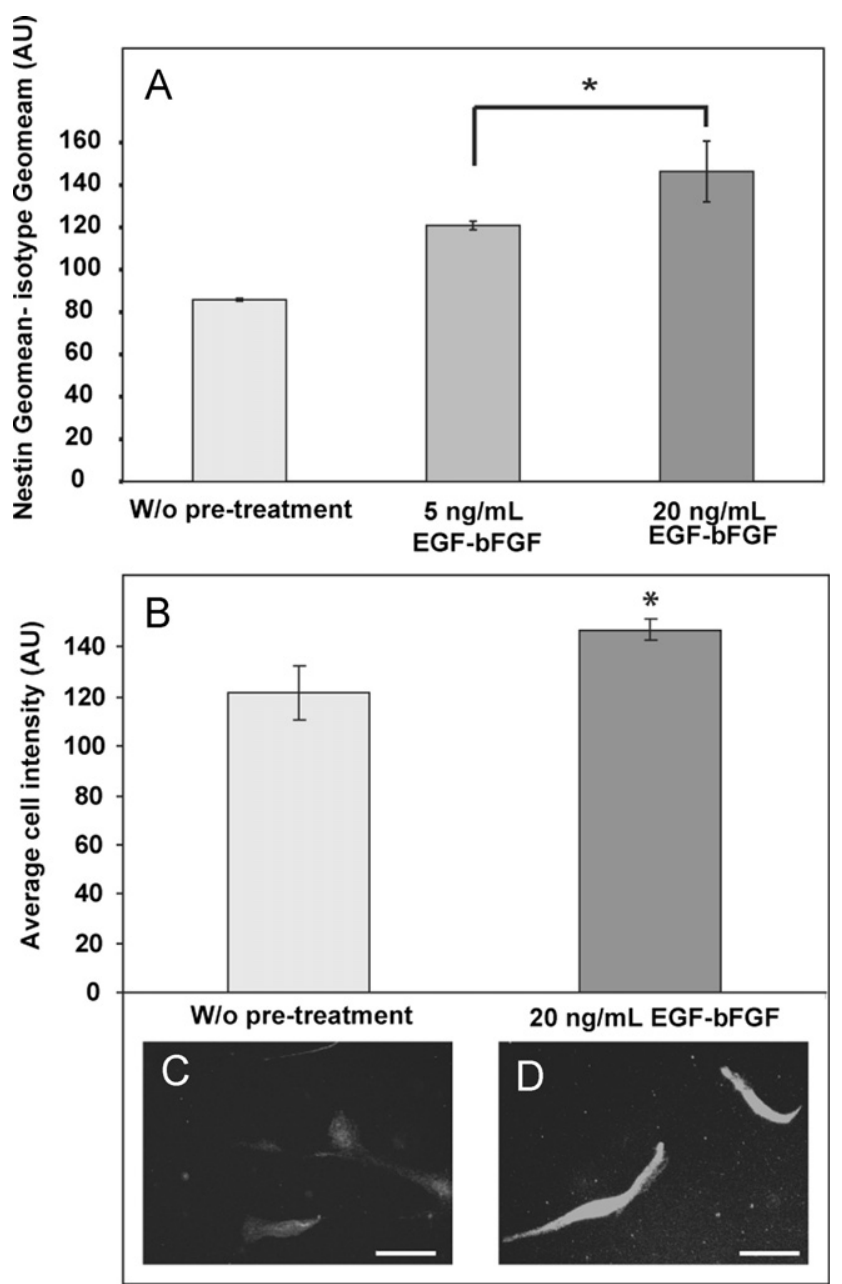

Fig. 1. Nestin up-regulation during EGF-bFGF pre-treatment. Nestin expression by MIAMI cells increased after exposure to EGF-bFGF, as observed by flow cytometry (A). Immunocytofluorescence (B) confirmed that non-treated cells (C) expressed a lower amount of nestin compared to EGF-bFGF treated cells (D). Depicted results were obtained from a representative experiment and differences were considered significant at $P \leq 0.05^{*}$. Scale bars: $50 \mu \mathrm{m}$. Abbreviation: ICF, immunocytofluorescence. including Nestin, Microtubule-associated protein $1 b$ (MAP1b), Musashi homolog 1 (Msi1), Notch1, Hairy and enhancer of split 5 (HES5), Paired box 6 (Pax6) and Neurogenin 2 (Ngn2). The expression of Nestin was stimulated $(2.9 \pm 0.8$-fold increase) by the EGF-bFGF treatment and this was confirmed by flow cytometry and immunocytofluorescence with 5 and $20 \mathrm{ng} / \mathrm{mL}$ EGF-bFGF (Fig. 1), while a higher concentration $(50 \mathrm{ng} / \mathrm{mL})$ did not further increase Nestin expression. Moreover, Nestin was detected in almost all non-treated or treated cells, but its expression always remained lower than for NSCs used as a positive control (data not shown). Pax6 increased after $20 \mathrm{ng} / \mathrm{mL}$ EGF-bFGF treatment $(1.8 \pm 0.1$-fold increase), whereas the expression of Notch1, which plays a role in the control of NSC proliferation, slightly decreased ( $1.4 \pm 0.1$-fold decrease). Expression of HES5 decreased and became almost undetectable while Ngn2 increased (2.1 \pm 0.1 -fold increase), possibly as a consequence of Notch1 down-regulation. Importantly, expression of stem and early neural-related genes was similar for iliac crestderived MIAMI cells isolated from an older individual, with equivalent changes induced in response to EGF-bFGF exposure. All these results illustrate an EGF-bFGF-induced specification of the MIAMI cells toward a neural phenotype, independently from their anatomical site of origin, i.e. vertebral bodies or iliac crest.

A

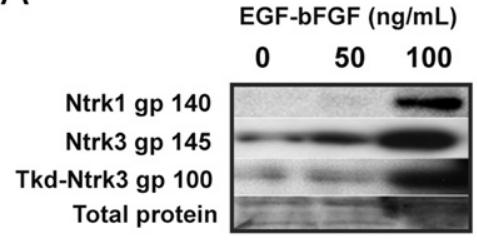

B

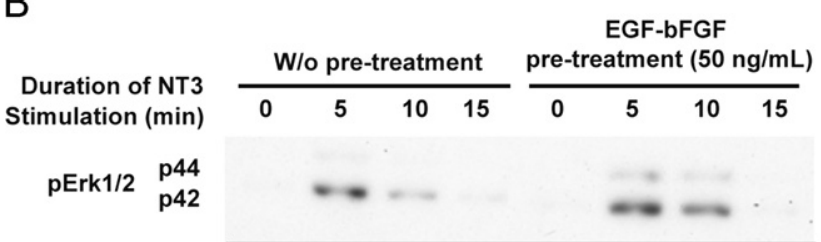

Total Erk1/2

C

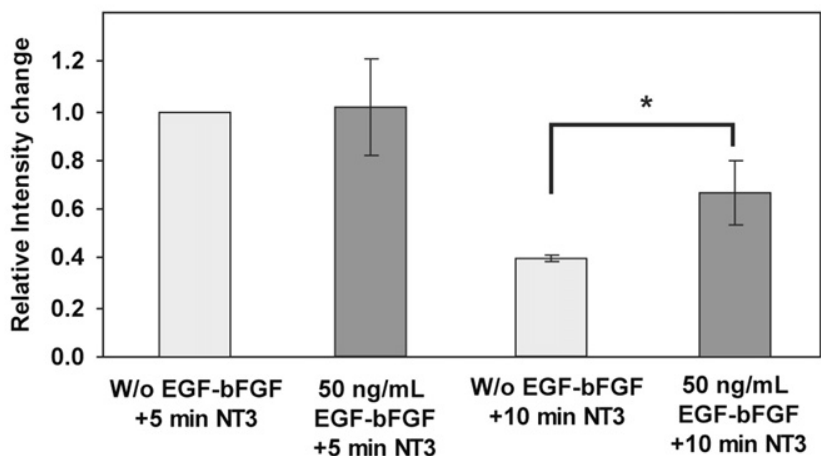

Fig. 2. Representative Ntrk up-regulation and Erk-sustained phosphorylation. During EGF-bFGF pre-treatment, expression by MIAMI cells of Ntrk1, Ntrk3 and Tkd-Ntrk3 receptors were strongly up-regulated $(\mathrm{A})$. Total proteins were detected by Coomasie blue staining. In response to NT3 stimulation, Erk phosphorylation peaked after 5 min and decreased at $10 \mathrm{~min}$ for non-pre-treated cells. After $50 \mathrm{ng} / \mathrm{mL}$ EGF-bFGF pretreatment, pErk peaked at $5 \mathrm{~min}$ and remained at a high level at $10 \mathrm{~min}$ of NT3 stimulation, compared to non-pre-treated cells. This sustained phosphorylation was similar for $\mathrm{p} 42$ and $\mathrm{p} 44$ (B, C). *Differences were considered significant at $P \leq 0.05$ Abbreviations: Ntrk: neurotrophic tyrosine kinase receptor. (A) Wtrk WB; (B) Erk WB and (C) Averaged normalized p42/44 phoshporylation. 


\subsection{Effects of EGF-bFGF on the NT3 transduction pathway}

Analysis of the NT3 receptor, neurotrophin tyrosine receptor kinase 3 (Ntrk3), revealed that both the full-length isoform (gp145, FL-Ntrk3) and the tyrosine kinase deficient isoform (gp100, Tkd-Ntrk3) of Ntrk3 were up-regulated along with Ntrk1, after $50 \mathrm{ng} / \mathrm{mL}$ EGF-bFGF treatment (Fig. 2A), while lower concentrations did not result in significant changes. However, EGF-bFGF treatment did not further up-regulate Ntrk3 expression in iliac-crest-isolated MIAMI cells, which express relatively higher

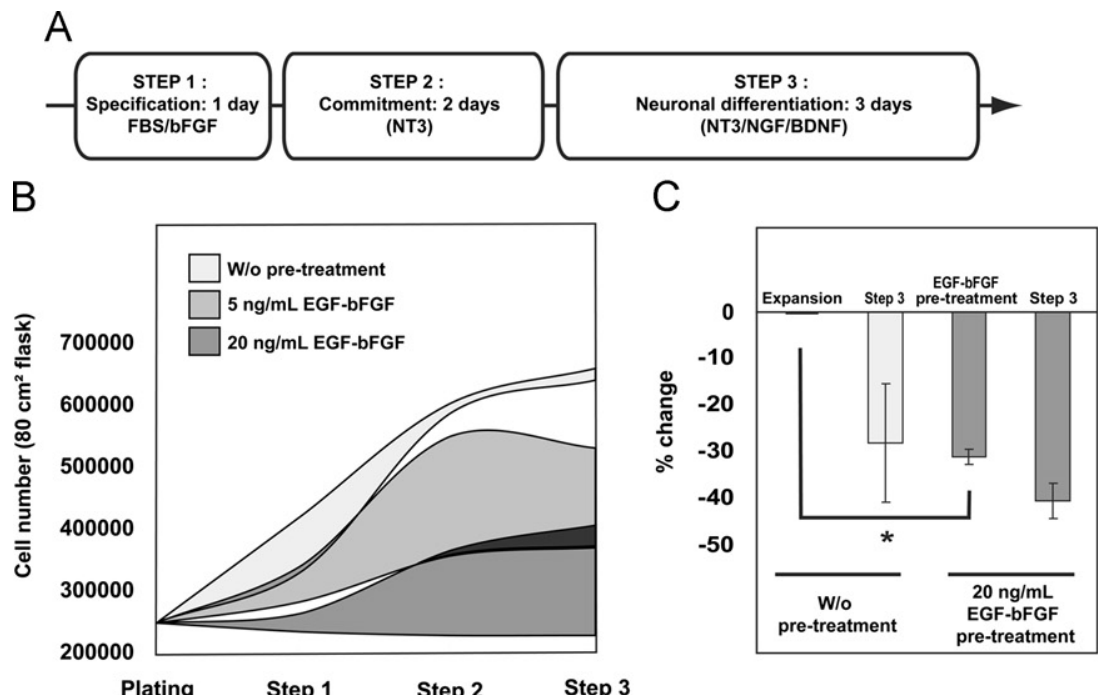

D

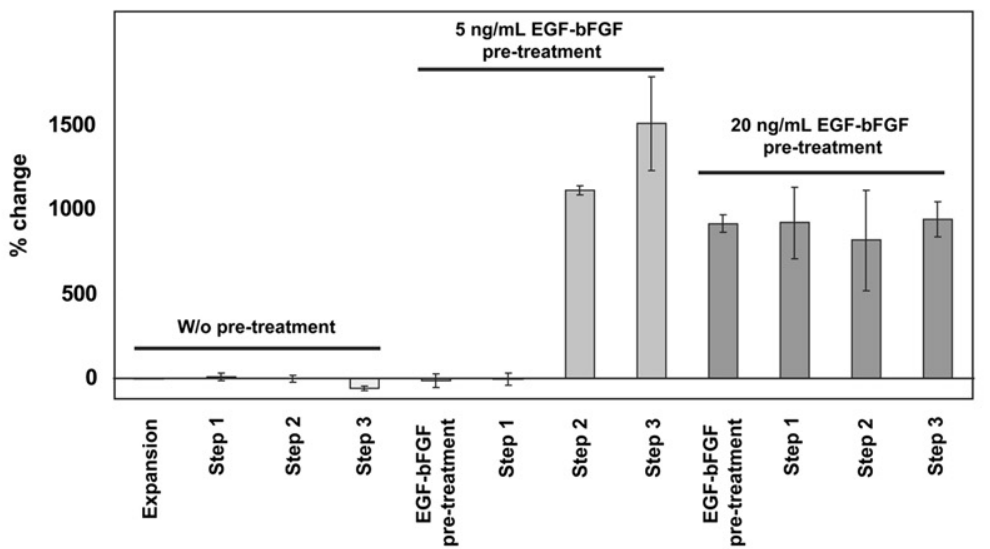

$E$

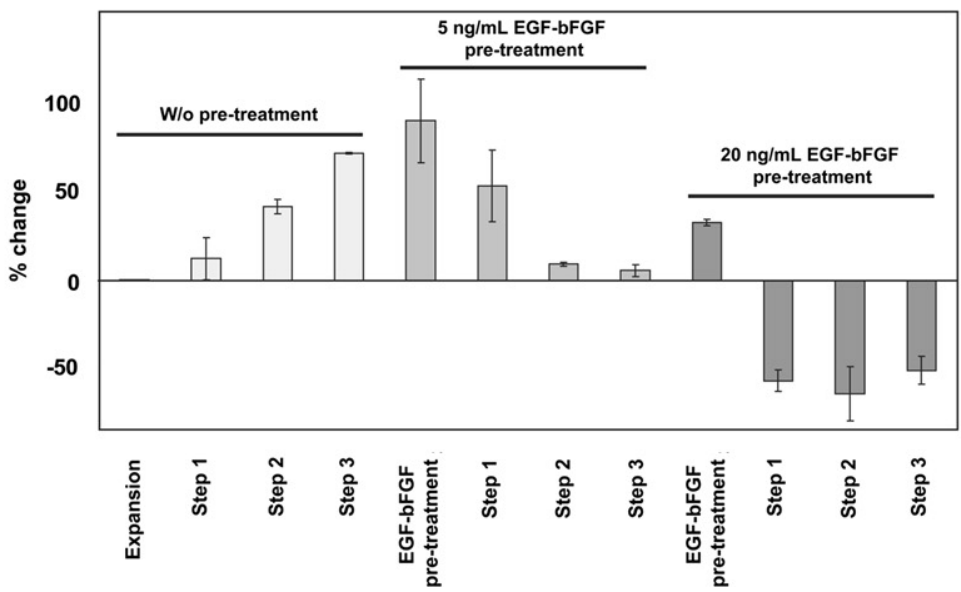

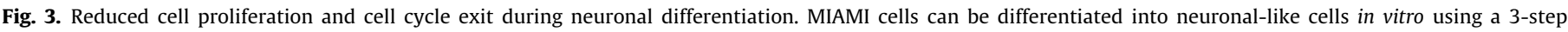

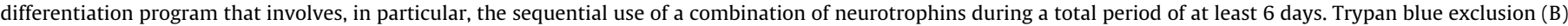

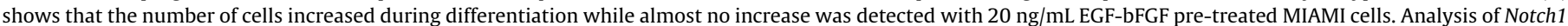

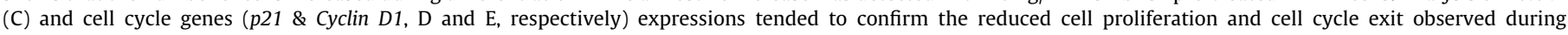

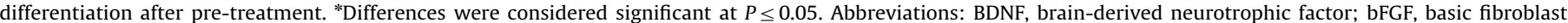
growth factor; FBS, foetal bovine serum; NGF, nerve growth factor; NT3, neurotrophin 3. 
basal levels of this receptor. In these cells, NT3 stimulation (30ng/mL) induced Erk1/2 phosphorylation (p42/p44), which peaked after $5 \mathrm{~min}$, decreased after $10 \mathrm{~min}$ and was not detectable after $15 \mathrm{~min}$ of stimulation. EGF-bFGF treatment resulted in a more sustained phosphorylation of pErk1/2 (p42 and p44: $p \leq 0.05$ ), still present at $10 \mathrm{~min}$ of NT3 stimulation compared to non-treated cells (Fig. 2B and C). This result shows a differential response to NT3 stimulation after EGF-bFGF treatment, suggesting that the pre-treatment may permit the cells to better respond to NT3 during the neuronal differentiation.

\subsection{Effects of EGF-bFGF pre-treatment during neuronal differentiation}

To better understand the effects of the EGF-bFGF treatment, we describe in this second section its effects on the neuronal differentiation potential of MIAMI cells.

\subsection{Decreased proliferation during neuronal differentiation}

The antiproliferative gene p21 was up-regulated during EGF-bFGF treatment $(10.2 \pm 0.7$-fold increase) and Trypan blue counting suggested that cell doubling rate was reduced after exposure to EGF-bFGF. This reduced cell-doubling rate was also observed during differentiation when cells were pre-treated with $5 \mathrm{ng} / \mathrm{mL}$ EGF-bFGF, while cell-doubling was almost abolished with $20 \mathrm{ng} / \mathrm{mL}$ EGF-bFGF pre-treatment (Fig. 3B). Notch1 expression, which was already down-regulated after EGF-bFGF treatment, further decreased during neuronal differentiation, both for non-pre-treated and EGF-bFGF pre-treated cells (Fig. 3C). Moreover, expression of the cell cycle markers $p 21$ and Cyclin D1 at the RNA level confirmed the decreased proliferation observed during differentiation after pre-treatment (Fig. 3D and E). Indeed, p21 was low in non-pre-treated cells, it increased during differentiation in $5 \mathrm{ng} / \mathrm{mL}$ pre-treated cells and it was already elevated after $20 \mathrm{ng} / \mathrm{mL}$ pre-treatment, prior to the beginning of the differentiation. Conversely, Cyclin D1 expression was high in non-pre-treated cells and increased during differentiation. In $5 \mathrm{ng} / \mathrm{mL}$ EGF-bFGF pre-treated cells, Cyclin D1 decreased during differentiation whereas it was always low in cells pre-treated with a higher dose of EGF-bFGF. Importantly, dead cells were never detected during neuronal differentiation, with or without pre-treatment. To further confirm that there was no contribution from apoptosis to the reduced proliferation rate observed, a Caspase-3 apoptosis assay was performed. No Caspase-3 activity was detected, strongly suggesting that MIAMI cells, pre-treated or not with EGF-bFGF, did not undergo detectable apoptosis. In addition, it is interesting to note that at the end of differentiation, non-pre-treated and EGF-bFGF pre-treated cells were sensitive to an apoptotic stress induced by $1 \mu \mathrm{g} / \mathrm{mL}$ staurosporine (Fig. 4A). When exposed to staurosporine, the cells exhibited an increased Caspase 3 activity as well as a retracted morphology and nucleus fragmentation (Fig. $4 \mathrm{~B}$ and $\mathrm{C}$ ). However, under expansion conditions, both non-pre-treated and pre-treated MIAMI cells seemed to be resistant to the proapoptotic inducer staurosporine as Caspase-3 activity was never detected (Fig. 4A).

\subsection{Homogeneous cell morphology and induced neurite extensions}

Under low density expansion conditions, MIAMI cells are very small, slightly bipolar cells with a reduced cytoplasm compared to traditional MSCs. When treated with a combination of EGF-bFGF, MIAMI cells exhibited an even more homogeneous morphology with a refractile body, compared to non-treated cells (Fig. 5A and B). In addition, EGF-bFGF pre-treatment resulted in important morphological changes reminiscent of neurons at the end of the differentiation protocol (step 3). During the 6 days of neuronal differentiation, the small MIAMI cells gradually extended, thereby acquiring a neuron-like morphology with long neurite-like extensions (Fig. 5C and D). The total cell length could achieve more than $400 \mu \mathrm{m}$ at the end of the differentiation when the EGF-bFGF
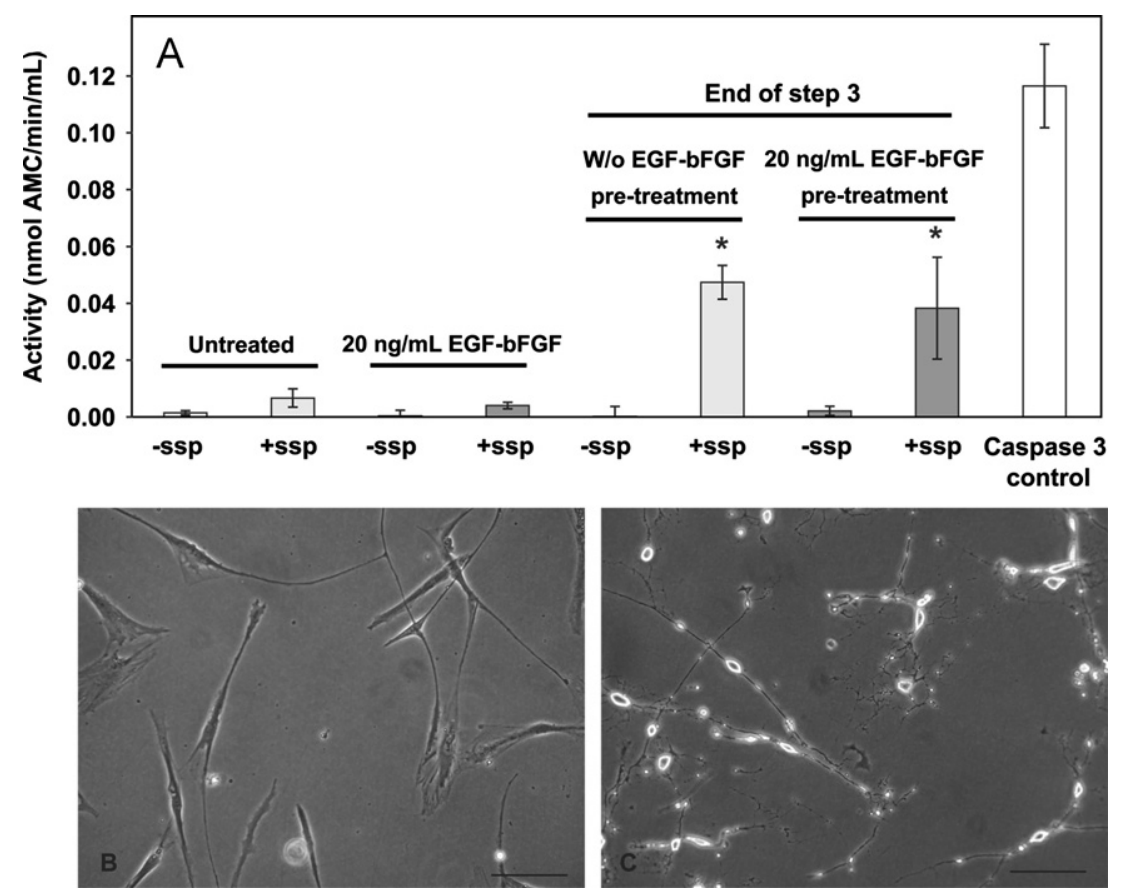

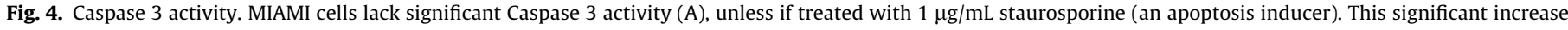

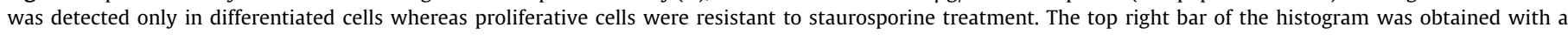

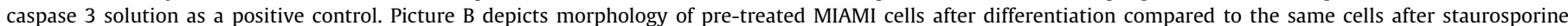
exposure (C). *Significantly different medians at $P \leq 0.05$. Scale bars: $100 \mu \mathrm{m}$. Abbreviation: Ssp, staurosporine. 
pre-treatment was applied (Table 2). EGF-bFGF pre-treated cells were also thinner than non-pre-treated cells (Fig. 5C and D and Table 2), and numerous connexions could be observed by SEM at the end of differentiation (Fig. 5E and F). Similar morphological changes were observed during neuronal differentiation when pre-treating iliac crest-isolated MIAMI cells with the EGF-bFGF pre-treatment.

\subsection{Improved neuronal expression pattern during neuronal differentiation}

Nestin expression was up-regulated during pre-treatment and its expression decreased during differentiation as observed by immunocytofluorescence at the end of step 3 and even more drastically after 12 days of step 3 (data not shown). The pattern of
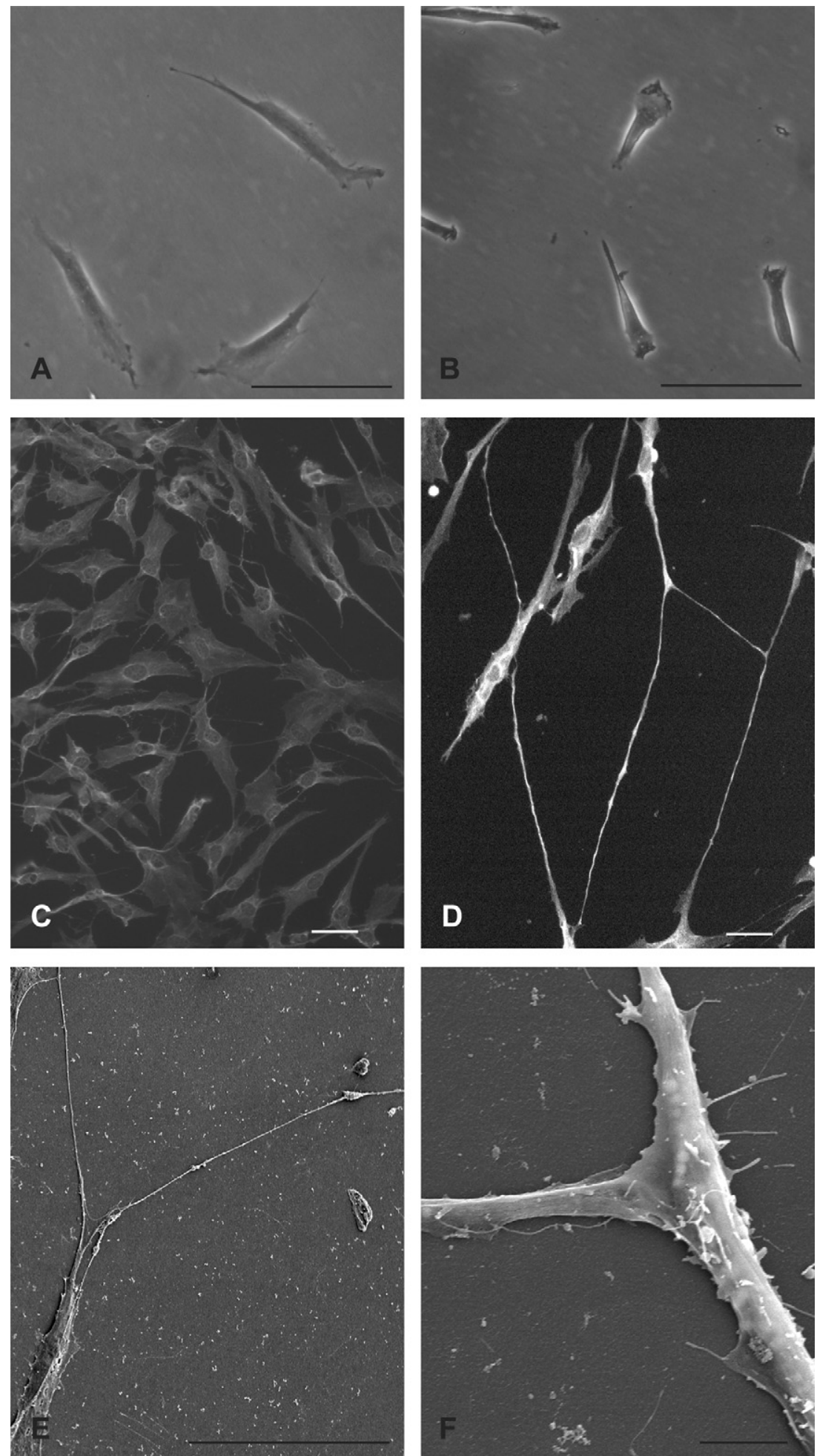

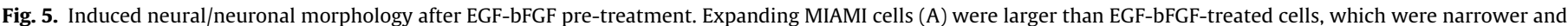

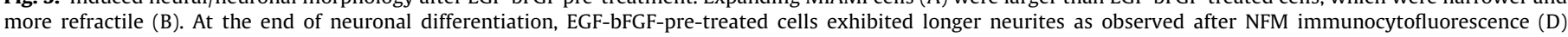

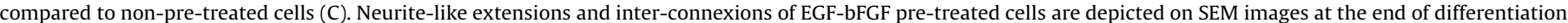
(E, F, respectively). Scale bars A-E: $100 \mu \mathrm{m} ; \mathrm{F}: 5 \mu \mathrm{m}$. 
expression of the early neuronal marker $\beta 3$-Tubulin followed the neuronal developmental program only if cells were pretreated with EGF-bFGF. $\beta 3$-Tubulin mRNA increased during neuronal differentiation before decreasing at the end of step 3 (Fig. 6A). Moreover, its expression was already high after pre-treatment compared to non-pre-treated cells. Using immunocytofluorescence, $\beta 3$-Tubulin expression at the end of steps 2 and 3 was always significantly higher for EGF-bFGF pretreated cells compared to non-pre-treated cells, both in terms of the percentage of $\beta 3$-Tubulin-expressing cells and marker intensity (Fig. 6B and E).

The mRNA expression of the neuronal marker Neurofilament medium (NFM) underwent a strong decrease at the end of step 3 for non-pre-treated cells. In contrast, expression of NFM increased throughout the differentiation protocol when the pre-treatment was

Table 2

Cell area and length at the end of differentiation.

\begin{tabular}{lcc}
\hline & $\begin{array}{l}\text { Non pre-treated } \\
\text { cells }\end{array}$ & $\begin{array}{l}\text { EGF-bFGF pre- } \\
\text { treated cells }\end{array}$ \\
\hline Cell area $\left(\boldsymbol{\mu m}^{2}\right)$ & $4378 \pm 665$ & $2893 \pm 499^{*}$ \\
Cell length $(\mu \mathrm{m} \pm \mathrm{SD})$ & $289 \pm 43$ & $421 \pm 50^{*}$ \\
\hline
\end{tabular}

EGF-bFGF pre-treated cells exhibited a decreased cell area (i.e. a narrower cell body) and an increased cell length, due to the presence of long neurite-like extensions at the end of step 3. Data represent the average length of the 3 longer cells of 5 different images in a representative experiment.

* Significantly different means at $P \leq 0.05$. used (Fig. 6C). Similarly to $\beta 3$-Tubulin, NFM protein expression was higher for pre-treated cells at the end of step 3 (Fig. 6D and E). Assessment of $\beta 3$-Tubulin expression at the end of step 2 , by immunocytofluorescence, confirmed that removal of NT3 lowered the percentage of $\beta 3$-Tubulin-positive cells (data not shown) as previously described (Tatard et al., 2007). In a similar manner the mRNA expression of the three neurofilaments, Neurofilament light (NFL), NFM and Neurofilament heavy (NFH) was up-regulated at the end of step 2 when iliac crest-isolated MIAMI cells were pre-treated with $20 \mathrm{ng} / \mathrm{mL}$ (data not shown) or $50 \mathrm{ng} / \mathrm{mL}$ EGF-bFGF compared to non-pretreated cells (Fig. 7). These results further support the role of NT3 on the neuronal differentiation of MIAMI cells. Importantly, use of an Erk inhibitor (U0126) added prior (1 h) to NT3 stimulation, decreased the expression of these three markers, down to a level similar to that observed without EGF-bFGF pre-treatment, particularly for NFH (Fig. 7).

Finally, the unphosphorylated microtubule-associated protein Tau, characteristic of immature neurons, was readily detectable throughout the neuronal differentiation procedure by Western blot analysis while we did not detect its phosphorylated form (data not shown). The major changes observed with and without EGF-bFGF pre-treatment before and during neuronal differentiation are summarized in Table 3.

\subsection{Neuronal neurotransmitter phenotypes during neuronal differentiation}

Acetylcholinesterase (AChE), expressed by cholinergic and noradrenergic neurons, was detected at very low level by
A

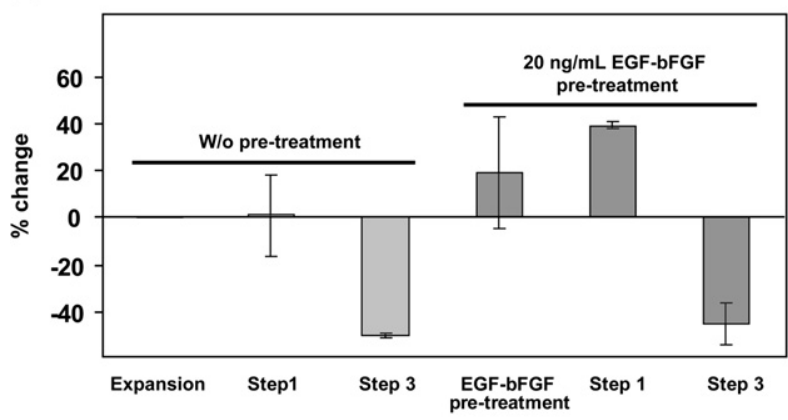

C

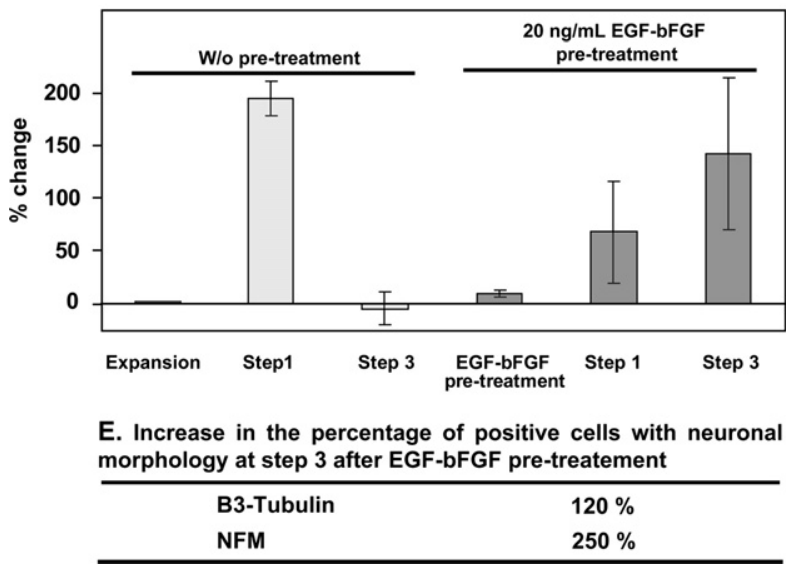

B

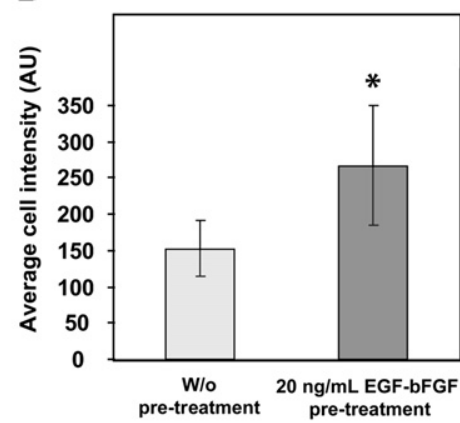

D

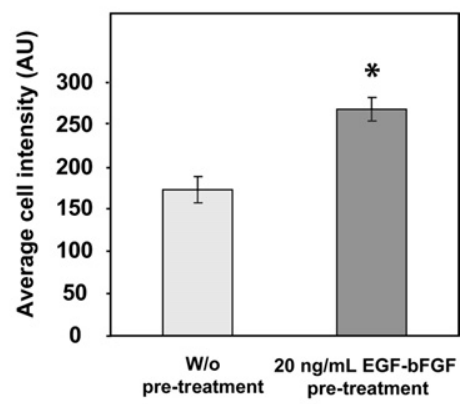

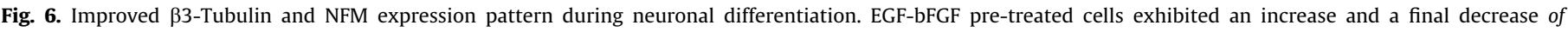

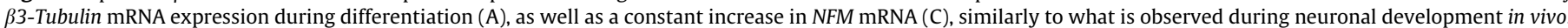

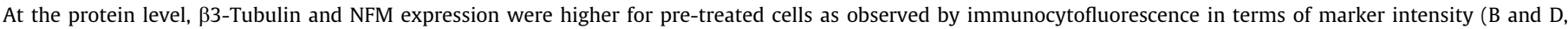

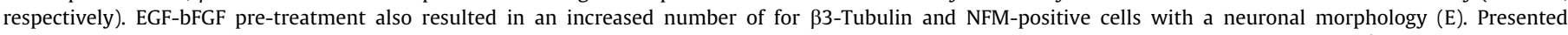

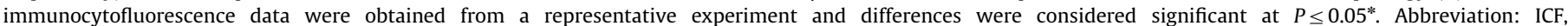
immunocytofluorescence. 


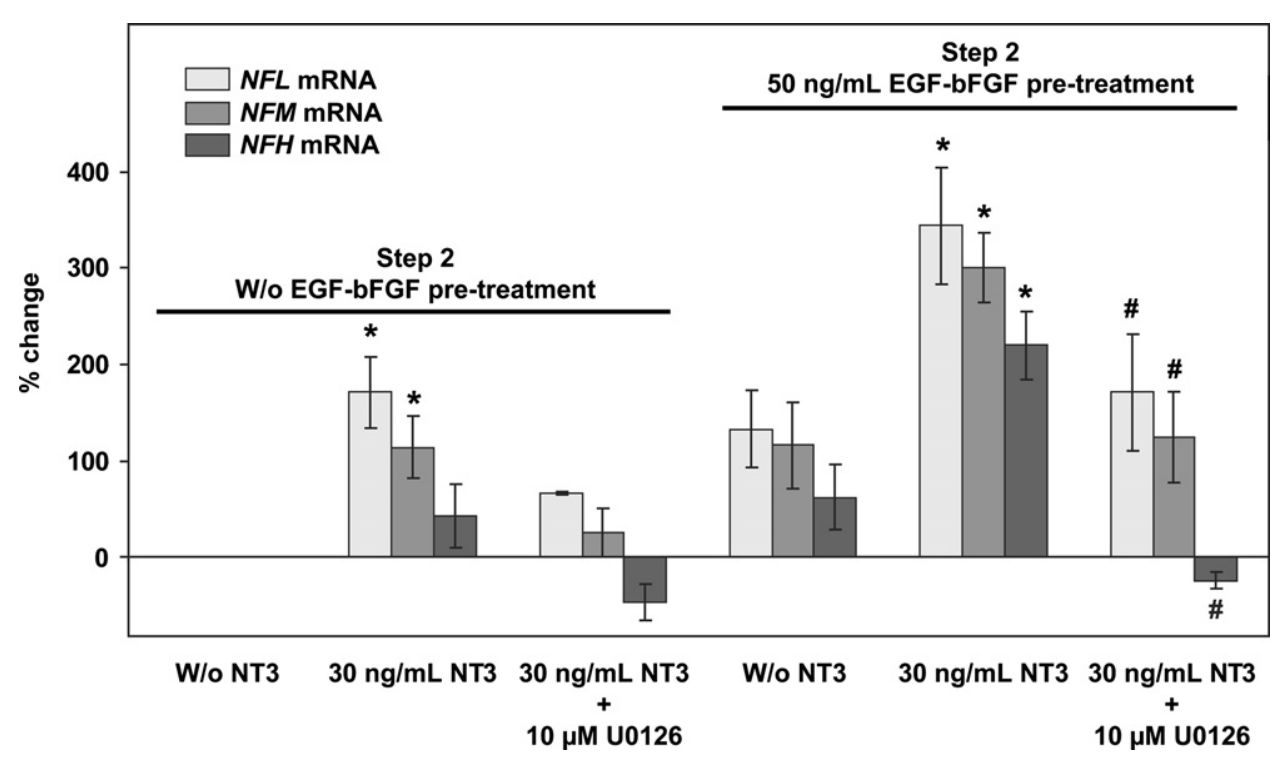

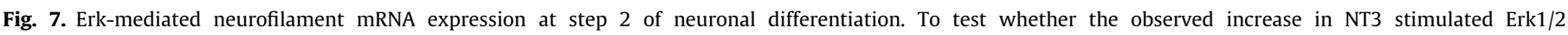

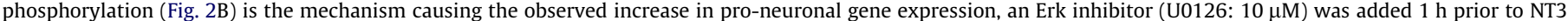

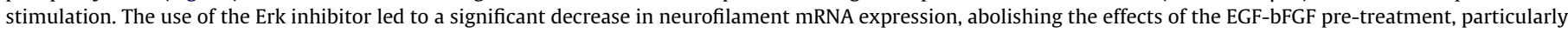

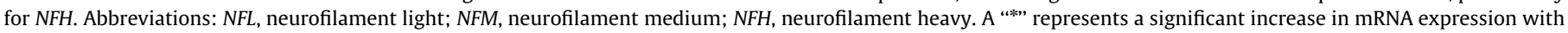
NT3 compared to without NT3. A “\#” represents a significant decrease with U0126 compared to without U0126. Changes were considered significant at $P \leq 0.05$.

RT-qPCR during expansion and tended to increase during neuronal differentiation (10.4 \pm 3.3 -fold increase) when cells were pre-treated with EGF-bFGF. Glutamate decarboxylase (GAD 25/67), expressed by GABAergic neurons, Choline acetyltransferase (ChAT), another cholinergic phenotype enzyme and dopaminergic markers (Tyrosine hydroxylase (TH), Dopamine transporter (DAT) and Nurr1) were not detected or at very low levels.

\subsection{Glial phenotypes during neuronal differentiation}

Galactosylceramidase (GalC), characteristic of oligodendrocytes, was slightly expressed by MIAMI cells and further increased during neuronal differentiation for pre-treated cells, whereas its expression does not significantly vary in non-pre-treated cells (Fig. 8A). In opposition, Oligodendrocyte lineage transcription factor 2 (Olig2), another early marker of oligodendrocytes, was never detected in MIAMI cells. Glial fibrillary acidic protein (GFAP), specific of astrocytes, was not detected at the end of the differentiation. Previous results suggested that an insulin, transferin, selenium and lipids complement (ITS +3 ) improved cell morphology and membrane potential when used in step 3 (data not shown). However, when cultured in this lipid rich medium all along the differentiation protocol, numerous perinuclear lipid vesicles appeared at the end of step 2 and remained until the end of step 3 , in a more significant manner for pre-treated cells, as observed with oil red staining (Fig. 8C and D). The lipid nature of these vesicles was confirmed using backscattered electron SEM imaging (Fig. 8B), with visualization of osmium on double bonds-molecules-rich sites.

\subsection{Mesodermal phenotypes during neuronal differentiation}

We analysed the expression of several genes related to mesodermal phenotypes, the major differentiation pathways of MSCs. Sox9, specific to chondrogenic progenitors, was slightly upregulated during neuronal differentiation of non-pre-treated cells $(1.5 \pm 0.1$-fold increase); whereas it was down-regulated when cells were pre-treated with EGF-bFGF $(2.5 \pm 0.6$-fold decrease), thereby underlining the importance of the pre-treatment for neuronal differentiation purposes. The osteo-chondro marker Runt-related transcription factor 2 (Runx2) was always detected at very low levels, while the osteogenic marker Osterix (Sp7) was never detected. Peroxisome proliferator-activated receptor gamma (PPAR gamma), commonly related to the adipogenic/neurogenic lineage, was expressed by MIAMI cells. It was further upregulated during differentiation, without significant changes with or w/o pre-treatment $(11.4 \pm 4.0$-fold increase) whereas the solely adipogenic Lipoprotein lipase $(L p L)$ was never detected. Noteworthy, exposure to ITS +3 during neuronal differentiation, described in the previous section, did not affect PPAR gamma expression and $L p L$ remained undetected.

\section{Discussion}

The differentiation of MSC subpopulations into neuron-like cells, a tightly controlled process involving a series of stimuli, has been recently reviewed (Ross and Verfaillie, 2008). In order to be able to use these cells for regenerative medicine studies in the brain, it is important to have a deeper understanding of the molecular events mediating this process. Even though miRNAs may have an important role in neurogenesis, their contribution was not investigated in the present paper (Chen et al., 2010; Greco and Rameshwar, 2007). We have demonstrated that an EGF-bFGF treatment of human MIAMI cells, a subpopulation of MSCs, initiated their cell cycle exit and directed their gene expression pattern toward a neural/neuronal lineage. In addition, we reported in a previous study that NT3 was essential for the differentiation of MIAMI cells to cells with morphological, biochemical and electrophysiological characteristics of immature neurons (Tatard et al., 2007). In the present study, we observed that Ntrk1 and Ntrk3 receptors, both mediators of NT3 responses (Reichardt, 2006; Ivanisevic et al., 2007), were up-regulated after EGF-bFGF treatment, a process accompanied with a more sustained phosphorylation of Erk in response to NT3. In this 
Table 3

Major effects of MIAMI cells exposure to EGF-bFGF.

\begin{tabular}{|c|c|c|}
\hline Markers & Down/up-regulation & Fold change (RT-qPCR) \\
\hline \multirow{2}{*}{\multicolumn{3}{|c|}{$\begin{array}{l}\text { EGF-bFGF treatment } \\
\text { Transcription factors }\end{array}$}} \\
\hline & & \\
\hline Notch1 & $\downarrow$ & $1.4+0.1$ \\
\hline Ngn2 & $\uparrow$ & $2.1 \pm 0.1$ \\
\hline HES5 & $\downarrow$ & Undetectable \\
\hline Pax6 & $\uparrow$ & $1.8 \pm 0.1$ \\
\hline \multicolumn{3}{|l|}{ Filaments } \\
\hline Nes & $\uparrow$ & $2.9 \pm 0.8$ \\
\hline \multicolumn{3}{|l|}{ Cell cycle } \\
\hline P21 & $\uparrow$ & $10.2 \pm 0.7$ \\
\hline Cyclin D1 & \langle\rangle & $\mathrm{NC}$ \\
\hline \multicolumn{3}{|l|}{ Receptors } \\
\hline Ntrk1 & $\uparrow$ & ND \\
\hline Ntrk3 & $\uparrow$ & ND \\
\hline Tkd-Ntrk3 & $\uparrow$ & ND \\
\hline Proliferation rate & $\downarrow$ & \\
\hline \multicolumn{3}{|c|}{ Effects of EGF-bFGF pre-treatment during neuronal differentiation } \\
\hline \multicolumn{3}{|c|}{ Filaments } \\
\hline ß3-Tubulin & $\uparrow$ & $1.4 \pm 0.3$ \\
\hline NFL & $\uparrow$ & $1.6 \pm 0.3$ \\
\hline NFM & $\uparrow$ & $1.9 \pm 0.3$ \\
\hline NFH & $\uparrow$ & $2.4 \pm 0.7$ \\
\hline \multicolumn{3}{|l|}{ Cell cycle } \\
\hline P21 & $\uparrow$ & $26.7 \pm 14.7$ \\
\hline Cyclin D1 & $\downarrow$ & $3.6 \pm 0.8$ \\
\hline \multicolumn{3}{|l|}{ Oligodendrocyte } \\
\hline GalC & $\uparrow$ & $4.4 \pm 3.1$ \\
\hline Proliferation rate & $\downarrow$ & \\
\hline
\end{tabular}

Exposure of MIAMI cells to EGF-bFGF resulted in the differential expression of a large panel of markers, as observed using RT-qPCR, western blot, flow cytometry and immunocytofluorescence, thereby suggesting a neural specification of the cells. If observed, changes in gene expression calculated by RT-qPCR are expressed as fold change. After EGF-bFGF pre-treatment and further exposure to the neuronal induction media, an increased expression of various neuronal filamentous proteins was observed, compared to differentiated, but non-pre-treated MIAMI cells. In addition, a reduced proliferation rate during neuronal differentiation was observed only with EGF-bFGF pre-treated MIAMI cells, in accordance with a higher expression of $P 21$ and a down-regulation of Cyclin D1. Thus, these results show that EGF and bFGF pre-treatment enhance the response of MIAMI cells to neuronal commitment. Abbreviations: NC: no changes, ND: not determined by RT-qPCR.

way, EGF-bFGF treatment enables the cells to better respond to the neuronal differentiation stimuli. We effectively observed that, during the induction protocol, EGF-bFGF-pre-treated MIAMIderived neuron-like cells stopped proliferating, presented longer neurite extensions and acquired an expression pattern more consistent with a neuronal differentiation program. To better understand the enhanced effect of the EGF/bFGF pre-treatment on the NT3-induced commitment of the MIAMI cells toward a neuronal differentiation and the relation with Erk activation, an Erk specific inhibitor was used. In the presence of the Erk inhibitor, the up-regulation of the neurofilaments observed during neuronal differentiation when cells were pre-treated with EGF-bFGF was abolished, thereby underlining the role of this signaling pathway in this event. In addition, the same ablation was seen while using the Erk inhibitor during normal neuronal differentiation, suggesting that the Erk pathway is required for the NT3 stimulated up-regulation of pro-neuronal genes. This would indicate that bone marrow-derived MIAMI cells have a similar response to NT3 as compared with neural stem cells during development, in which the Ras-Raf-Mek-Erk signaling cascade is central for neurogenesis (Bibel and Barde, 2000). One hypothesis would be that the observed increase in NT3 stimulated Erk phosphorylation is due to the EGF-bFGF-induced up-regulation of the Ntrk3 receptor. These results shed light on the molecular events induced by an EGF-bFGF pre-treatment during the neuronal differentiation of MSC subpopulations. Thus, this pretreatment may increase the benefit of using MSCs for regenerative medicine approaches of the nervous system.

MIAMI cells have a broad differentiation potential, express embryonic markers, including Rex1 and SSEA synthase (D'Ippolito et al., 2004; Tatard et al., 2007), as well as Oct4A, described as essential for the pluripotency and self-renewal properties of stem cells (Masui et al., 2007; Boyer et al., 2005; Liedtke et al., 2008). The latter was down-regulated over EGF-bFGF exposure, suggesting a certain commitment of the cells toward a differentiation program as previously suggested (Hermann et al., 2004). In this regard, a recent study demonstrates that Oct4 is required and sufficient to directly reprogram NSCs to pluripotency (Kim et al., 2009). Nestin expression by pluripotent stem cells is considered to be a prerequisite for the commitment of the cells toward the neural lineage (Shiota et al., 2007; Wislet-Gendebien et al., 2003) and this intermediate filament protein is commonly used to identify NSCs and neural precursors (Gilyarov, 2008), even if its expression may be found in other cell types. Using flow cytometry, all MIAMI cells were found to express Nestin, as reported in other studies although results vary depending on the detection method, cell species and expansion method used (Tatard et al., 2007; Tondreau et al., 2004; Song et al., 2007; Hermann et al., 2004; Wislet-Gendebien et al., 2003). EGF-bFGF pre-treatment induced Nestin over-expression by MIAMI cells, as previously described for adherent or floating MSCs (Hermann et al., 2004; Long et al., 2005; Shiota et al., 2007); a mechanism that may be mediated through Erk pathway (Huang et al., 2009).

Notch1, which is involved in proliferation and maintenance of an undifferentiated state by NSCs (Kageyama et al., 2005), was down-regulated in response to EGF-bFGF treatment. Notch1 down-regulation could have led to the observed decreased expression of HES5 after EGF-bFGF pre-treatment (Kageyama et al., 2005). Characteristic of decreased HES5 expression is the up-regulation of the early neuronal marker Ngn2 (Kageyama et al., 2005), which we also observed after EGF-bFGF treatment. Noteworthy, this response has previously been described in Nestin expressing cells after treatment with bFGF (Vergano-Vera et al., 2009). Pax6, known to promote neurogenesis in neural stem cells (Kallur et al., 2008) was also up-regulated after pretreatment. These results suggest a potential progression of MIAMI cells toward a neuronal phenotype.

Cell cycle gene analysis and cell counting confirmed the propensity of EGF-bFGF pre-treated cells to decrease their proliferation rate during neuronal differentiation. Indeed, nonpre-treated cells exhibited a high level of Cyclin D1, the key cellcycle regulatory protein governing progression from the $\mathrm{G} 1$ to $\mathrm{S}$ phase, and low level of the antiproliferative gene p21, a Cyclindependent kinase and Proliferating cell nuclear antigen (PCNA) inhibitor (Luo et al., 1995). We can note that such a gene expression pattern is specific for integrin-mediated adhesion to fibronectin (Danen and Yamada, 2001), the substrate used in this study. Conversely, p21 was up-regulated in pre-treated cells, and remained at high level during neuronal differentiation, while Cyclin D1 was down-regulated. These events, which take place during the exit from the cell cycle, have already been described in the context of terminal differentiation (Pacary et al., 2006; Ekholm and Reed, 2000). In addition to its antiproliferative role, p21 may rescue human MSCs from apoptosis induced by low density culture (van den Bos et al., 1998), with p21 loss increasing apoptosis (Seoane et al., 2002). In our study, we did not observe apoptotic cells, either in low density expansion or in 

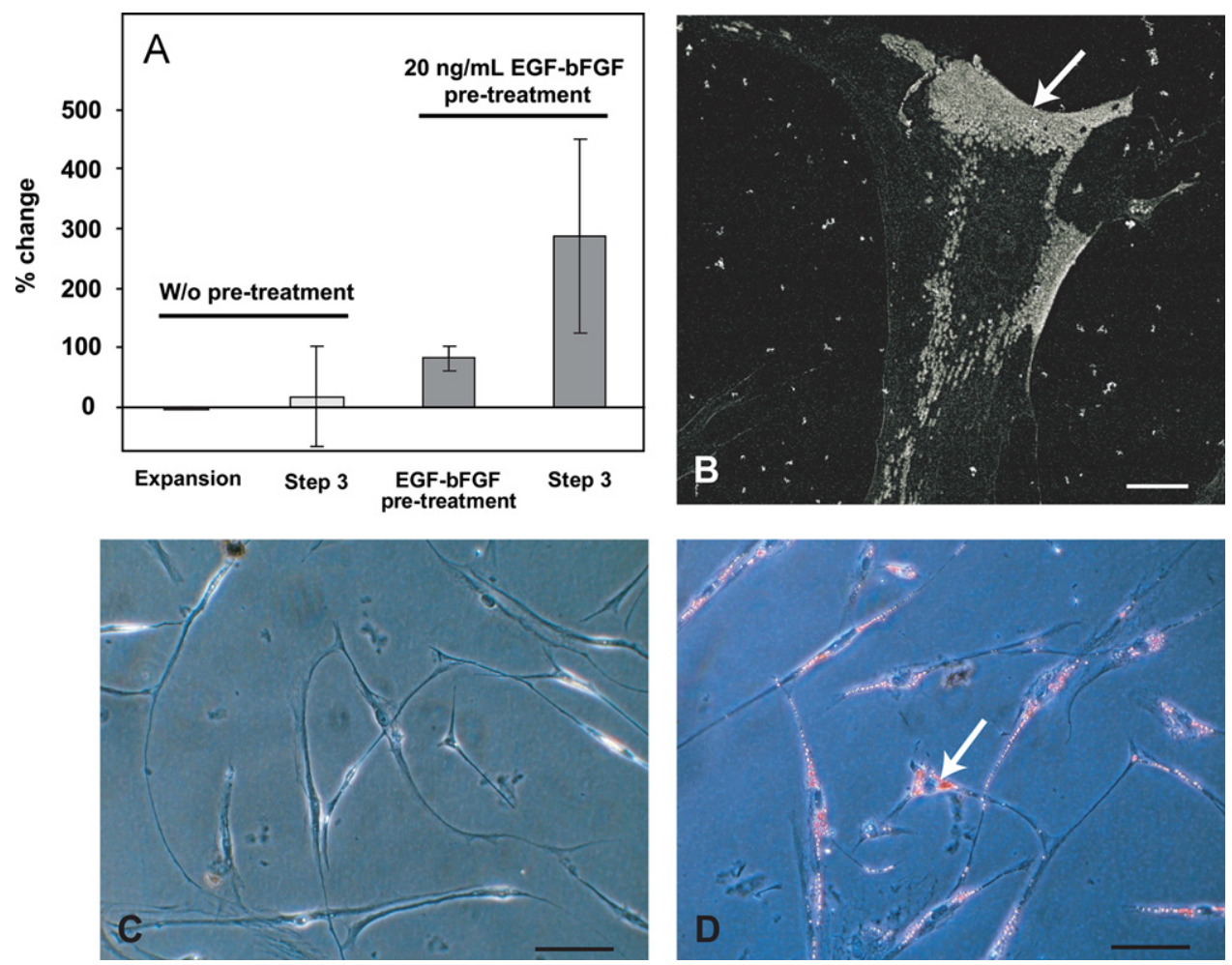

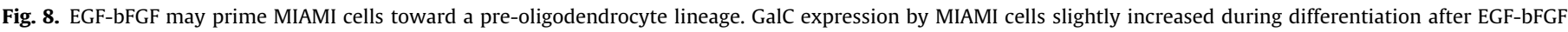

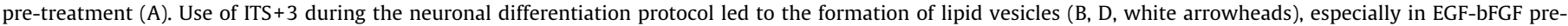

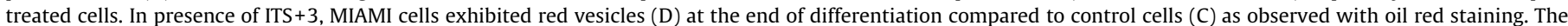

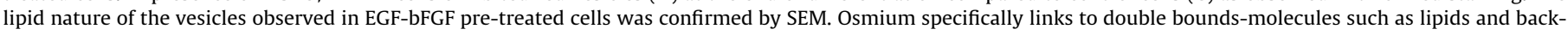

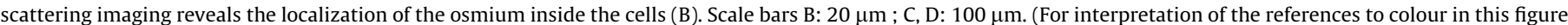
legend, the reader is referred to the web version of this article.)

differentiation. However, differentiated MIAMI cells became sensitive to the pro-apoptotic molecule used as a positive control, confirming a previous report made with MSCs (Pelletier et al., 2005). To explain this phenomenon, we may hypothesize that inhibition of Caspase 3, or of another related molecule, occurs in expansion and that this inhibition is abolished during differentiation. For example, the Heat shock protein Hsp20, highly expressed by MIAMI cells (data not shown), has recently been described to inhibit Caspase 3 via an interaction with the pro-apoptotic protein Bax (Fan et al., 2005a, 2005b).

Altogether, these results demonstrate that EGF-bFGF treatment induces the specification of MIAMI cells toward the neural lineage. During neuronal differentiation, cells exhibited a strong propensity to exit from the cell cycle, which suggests that they are on their way to ultimately become post-mitotic. Moreover, the neuronal gene expression pattern closely mimicked the neuronal developmental program. In vivo, Nestin is down-regulated during the switch from neural precursors to differentiated post-mitotic neurons (Gilyarov, 2008; Zimmerman et al., 1994), similarly to what we observed during differentiation of MIAMI cells by immunocytofluorescence. During the neuronal differentiation of pre-treated MIAMI cells, $\beta 3$-Tubulin expression pattern was also similar to that of neuronal precursors, with a first increase followed by a terminal decrease at the end of the neuronal differentiation protocol (Ginzburg et al., 1985). NFL, NFM and NFH expression increased during neuronal differentiation, therefore following the expression pattern observed during normal brain development (Moskowitz and Oblinger, 1995), whereas NFM decreased strongly at the end of step 3 for non-pre-treated cells. In support of these results, we observed by immunocytofluorescence that EGF-bFGF pre-treatment resulted in a stronger expression of NFM and to a certain extent of $\beta 3$-Tubulin at the end of step 3. Pre-treated cells exhibited narrower and longer neurite-like extensions consistent with the filamentous protein expression. Therefore, EGF-bFGF pre-treatment enhanced the neuronal differentiation ability of MIAMI cells and increased the expression of neurofilaments, including $N F H$, which appears late in development. However, a fully mature phenotype was still not obtained as the neuronal marker Tau was not detected in its phosphorylated form.

Without specific phenotype inducers, EGF-bFGF pre-treatment did not direct the neuronal differentiation toward a default neuronal pathway as mature neurotransmitter markers were only slightly detected. However, we previously demonstrated that MIAMI cells were able to differentiate toward the dopaminergic phenotype in response to the correct instructive cues, i.e. sonic hedgehog, fibroblast growth factor 8 and retinoic acid (Tatard et al., 2007).

For central nervous system cell therapy purposes, it is important to ascertain that MIAMI cells not only acquire a neuronal phenotype but also lose their mesodermal differentiation potential. In this study, differentiated MIAMI cells did not express osteogenic and adipogenic specific genes while the EGFbFGF pre-treatment induced a decreased expression of Sox9, present in chondrogenic progenitors (Marshall and Harley, 2000). Only PPAR gamma was up-regulated during differentiation, a marker commonly related to the adipogenic but also neurogenic lineages (Shiota et al., 2007; Casteilla et al., 2007; Cimini and Ceru, 2008; Wada et al., 2006), thereby playing a role in proliferation and differentiation of NSCs (Cimini and Ceru, 2008; Wada et al., 2006). Moreover, lipid droplets were never observed inside the cells, unless if differentiated in a lipid-rich medium supplemented 
with insulin, transferin and selenium, commonly used for neuronal differentiation purposes (Song et al., 2007; Okabe et al., 1996; Sanchez-Ramos et al., 2000; Tao et al., 2005; Levy et al., 2003). PPAR gamma expression and the ability to uptake lipids are also observed in oligodendrocyte cell lines (Roth et al., 2003). In this regard, the increased ability of differentiated EGFbFGF pre-treated cells to produce lipid vesicles may be related to the observed up-regulation of the oligodendrocyte specific gene GalC even if Olig 2, mainly involved in the development of oligodendrocyte lineage (Jakovcevski and Zecevic, 2005), was never detected. In addition, Notch1 down-regulation renders possible the oligodendrocytic differentiation of NSCs (Wang et al., 1998), suggesting that MIAMI cells may commit toward a neuronal and preoligodendrocytic lineage after EGF-bFGF pretreatment. In this respect, it has been proposed that some neurons and oligodendrocytes may share common progenitors during central nervous system development (Rowitch et al., 2002).

\section{Conclusions}

These results show that EGF-bFGF pre-treatment of MIAMI cells specified the cells toward the neural lineage and improved their neuronal differentiation program in vitro. In opposition to our method, others described culture of MSC spheroids in an EGFbFGF containing medium prior to neuronal differentiation, but many of the cells died in the process of sphere formation (Hermann et al., 2004). Importantly, MIAMI cells isolated from the iliac crest of living donors exhibited similar responses to the EGF-bFGF pre-treatment as MIAMI cells isolated from vertebral bodies, therefore allowing a simplified harvesting for autologous transplantation in clinical protocols. To our knowledge, this study is the first to precisely characterize the effects of an EGF-bFGF priming on human MSCs prior to neuronal differentiation. The results underline the advantages of pre-treating human MSCs with EGF-bFGF for neuronal differentiation purposes. In the future, EGF-bFGF pre-treatment may become an attractive, and easy to implement, method for enhancing the benefits of nervous system cell therapy based on the use of MSCs.

\section{Acknowledgments}

We thank the Service Commun d'Imagerie et d'Analyse Microscopique (SCIAM) of Angers for SEM images. We would also like to thank Laurence Preisser ("Service Commun de Cytométrie et d'Analyse Nucléotidique" (SCCAN), Angers), Laurence Sindji, David Vazquez, and Nubia Rodriguez for their precious technical assistance, as well as Dr. Micheline McCarthy (Department of Neurology, University of Miami) for supplying foetal neuroepithelial progenitor cells. This work was supported by the "Institut National de la Santé et de la Recherche Médicale", the "Région Pays de la Loire" and by grants from the Department of Veterans Affairs, USA.

\section{References}

Bang, O.Y., Lee, J.S., Lee, P.H., Lee, G., 2005. Autologous mesenchymal stem cell transplantation in stroke patients. Ann. Neurol. 57, 874-882.

Bithell, A., Finch, S.E., Hornby, M.F., Williams, B.P., 2008. Fibroblast growth factor 2 maintains the neurogenic capacity of embryonic neural progenitor cells in vitro but changes their neuronal subtype specification. Stem Cells 26, 1565-1574.

Barzilay, R., Kan, I., Ben-Zur, T., Bulvik, S., Melamed, E., Offen, D., 2008. Induction of human mesenchymal stem cells into dopamine-producing cells with different differentiation protocols. Stem Cells Dev. 17, 547-554.

Bibel, M., Barde, Y.A., 2000. Neurotrophins: key regulators of cell fate and cell shape in the vertebrate nervous system. Genes Dev. 14, 2919-2937.
Boyer, L.A., Lee, T.I., Cole, M.F., Johnstone, S.E., Levine, S.S., Zucker, J.P., Guenther, M.G., Kumar, R.M., Murray, H.L., Jenner, R.G., Gifford, D.K., Melton, D.A. Jaenisch, R., Young, R.A., 2005. Core transcriptional regulatory circuitry in human embryonic stem cells. Cell 122, 947-956.

van den Bos, C., Silverstetter, S., Murphy, M., Connolly, T., 1998. p21(cip1) rescues human mesnchymal stem cells from apoptosis induced by low-density culture. Cell Tissue Res. 293, 463-470.

Chen, X., Li, Y., Wang, L., Katakowski, M., Zhang, L., Chen, J., Xu, Y., Gautam, S.C., Chopp, M., 2002. Ischemic rat brain extracts induce human marrow stromal cell growth factor production. Neuropathology 22, 275-279.

Caldwell, M.A., Garcion, E., terBorg, M.G., He, X., Svendsen, C.N., 2004. Heparin stabilizes FGF-2 and modulates striatal precursor cell behavior in response to EGF. Exp. Neurol. 188, 408-420.

Chen, T.S., Lai, R.C., Lee, M.M., Choo, A.B., Lee, C.N., Lim, S.K., 2010. Mesenchymal stem cell secretes microparticles enriched in pre-microRNAs. Nucleic Acids Res. 38, 215-224.

Casteilla, L., Cousin, B., Carmona, M., 2007. PPARs and adipose cell plasticity. PPAR Res. 2007, 68202.

Cimini, A., Ceru, M.P., 2008. Emerging roles of peroxisome proliferator-activated receptors (PPARs) in the regulation of neural stem cells proliferation and differentiation. Stem Cell Rev. 4, 293-303.

Delcroix, G.J.R., Schiller, P.C., Benoit, J.-P., Montero-Menei, C.N., 2010. Adult cell therapy for brain neuronal damages and the role of tissue engineering. Biomaterials 31, 2105-2120.

Delcroix, G.J., Jacquart, M., Lemaire, L., Sindji, L., Franconi, F., Le Jeune, J.J., MonteroMenei, C.N., 2009. Mesenchymal and neural stem cells labeled with HEDPcoated SPIO nanoparticles: in vitro characterization and migration potential in rat brain. Brain Res. 1255, 18-31.

D’Ippolito, G., Diabira, S., Howard, G.A., Menei, P., Roos, B.A., Schiller, P.C., 2004 Marrow-isolated adult multilineage inducible (MIAMI) cells, a unique population of postnatal young and old human cells with extensive expansion and differentiation potential. J. Cell Sci. 117, 2971-2981.

Danen, E.H., Yamada, K.M., 2001. Fibronectin, integrins, and growth control. J. Cell Physiol. 189, 1-13.

Ekholm, S.V., Reed, S.I., 2000. Regulation of G(1) cyclin-dependent kinases in the mammalian cell cycle. Curr. Opin. Cell Biol. 12, 676-684.

Fan, G.C., Chu, G., Kranias, E.G., 2005a. Hsp20 and its cardioprotection. Trends Cardiovasc. Med. 15, 138-141.

Fan, G.C., Ren, X., Qian, J., Yuan, Q., Nicolaou, P., Wang, Y., Jones, W.K., Chu, G., Kranias, E.G., 2005b. Novel cardioprotective role of a small heat-shock protein, Hsp20, against ischemia/reperfusion injury. Circulation 111, 1792-1799.

Gotherstrom, C., Ringden, O., Tammik, C., Zetterberg, E., Westgren, M., Le Blanc, K., 2004. Immunologic properties of human fetal mesenchymal stem cells. Am. J. Obstet. Gynecol. 190, 239-245.

Guan, K., Chang, H., Rolletschek, A., Wobus, A.M., 2001. Embryonic stem cellderived neurogenesis. Retinoic acid induction and lineage selection of neuronal cells. Cell Tissue Res. 305, 171-176.

Gilyarov, A.V., 2008. Nestin in central nervous system cells. Neurosci. Behav Physiol. 38, 165-169.

Greco, S.J., Rameshwar, P., 2007. MicroRNAs regulate synthesis of the neurotransmitter substance $P$ in human mesenchymal stem cell-derived neuronal cells. Proc. Natl. Acad. Sci. USA 104, 15484-15489.

Ginzburg, I., Teichman, A., Dodemont, H.J., Behar, L., Littauer, U.Z., 1985. Regulation of three beta-tubulin mRNAs during rat brain development. EMBO J. 4 3667-3673.

Horwitz, E.M., Le Blanc, K., Dominici, M., Mueller, I., Slaper-Cortenbach, I., Marini, F.C., Deans, R.J., Krause, D.S., Keating, A., 2005. Clarification of the nomenclature for MSC: The International Society for Cellular Therapy position statement. Cytotherapy 7, 393-395.

Hermann, A., Maisel, M., Storch, A., 2006. Epigenetic conversion of human adult bone mesodermal stromal cells into neuroectodermal cell types for replacement therapy of neurodegenerative disorders. Expert Opin. Biol. Ther. 6, 653-670.

Hellmann, M.A., Panet, H., Barhum, Y., Melamed, E., Offen, D., 2006. Increased survival and migration of engrafted mesenchymal bone marrow stem cells in 6-hydroxydopamine-lesioned rodents. Neurosci. Lett. 395, 124-128.

Hermann, A., Gastl, R., Liebau, S., Popa, M.O., Fiedler, J., Boehm, B.O., Maisel, M. Lerche, H., Schwarz, J., Brenner, R., Storch, A., 2004. Efficient generation of neural stem cell-like cells from adult human bone marrow stromal cells. J. Cell Sci. 117, 4411-4422.

Huang, Y.L., Shi, G.Y., Lee, H., Jiang, M.J., Huang, B.M., Wu, H.L., Yang, H.Y., 2009. Thrombin induces nestin expression via the transactivation of EGFR signalings in rat vascular smooth muscle cells. Cell Signal.

Ivanisevic, L., Zheng, W., Woo, S.B., Neet, K.E., Saragovi, H.U., 2007. TrkA receptor "hot spots" for binding of NT-3 as a heterologous ligand. J. Biol. Chem. 282, 16754-16763.

Jendelova, P., Herynek, V., Urdzikova, L., Glogarova, K., Kroupova, J., Andersson, B. Bryja, V., Burian, M., Hajek, M., Sykova, E., 2004. Magnetic resonance tracking of transplanted bone marrow and embryonic stem cells labeled by iron oxide nanoparticles in rat brain and spinal cord. J. Neurosci. Res. 76, 232-243.

Jakovcevski, I., Zecevic, N., 2005. Olig transcription factors are expressed in oligodendrocyte and neuronal cells in human fetal CNS. J. Neurosci. 25, 10064-10073.

Kopen, G.C., Prockop, D.J., Phinney, D.G., 1999. Marrow stromal cells migrate throughout forebrain and cerebellum, and they differentiate into astrocytes 
after injection into neonatal mouse brains. Proc. Natl. Acad. Sci. USA 96, 10711-10716.

Kim, S., Honmou, O., Kato, K., Nonaka, T., Houkin, K., Hamada, H., Kocsis, J.D., 2006. Neural differentiation potential of peripheral blood- and bone-marrowderived precursor cells. Brain Res. 1123, 27-33.

Kim, J.B., Sebastiano, V., Wu, G., Arauzo-Bravo, M.J., Sasse, P., Gentile, L., Ko, K., Ruau, D., Ehrich, M., van den Boom, D., Meyer, J., Hubner, K., Bernemann, C., Ortmeier, C., Zenke, M., Fleischmann, B.K., Zaehres, H., Scholer, H.R., 2009. Oct4-induced pluripotency in adult neural stem cells. Cell 136, 411-419.

Kageyama, R., Ohtsuka, T., Hatakeyama, J., Ohsawa, R., 2005. Roles of bHLH genes in neural stem cell differentiation. Exp. Cell Res. 306, 343-348.

Kallur, T., Gisler, R., Lindvall, O., Kokaia, Z., 2008. Pax6 promotes neurogenesis in human neural stem cells. Mol. Cell. Neurosci. 38, 616-628.

Le Blanc, K., Tammik, C., Rosendahl, K., Zetterberg, E., Ringden, O., 2003. HLA expression and immunologic properties of differentiated and undifferentiated mesenchymal stem cells. Exp. Hematol. 31, 890-896.

Le Blanc, K., 2003. Immunomodulatory effects of fetal and adult mesenchymal stem cells. Cytotherapy 5, 485-489.

Li, Y., Chen, J., Chen, X.G., Wang, L., Gautam, S.C., Xu, Y.X., Katakowski, M., Zhang, L.J., Lu, M., Janakiraman, N., Chopp, M., 2002. Human marrow stromal cell therapy for stroke in rat: neurotrophins and functional recovery. Neurology 59 , 514-523.

Levy, Y.S., Bahat-Stroomza, M., Barzilay, R., Burshtein, A., Bulvik, S., Barhum, Y. Panet, H., Melamed, E., Offen, D., 2008. Regenerative effect of neural-induced human mesenchymal stromal cells in rat models of Parkinson's disease. Cytotherapy 10, 340-352.

Long, X., Olszewski, M., Huang, W., Kletzel, M., 2005. Neural cell differentiation in vitro from adult human bone marrow mesenchymal stem cells. Stem Cells Dev. 14, 65-69.

Liedtke, S., Stephan, M., Kogler, G., 2008. Oct4 expression revisited: potential pitfalls for data misinterpretation in stem cell research. Biol. Chem. 389, 845-850.

Luo, Y., Hurwitz, J., Massague, J., 1995. Cell-cycle inhibition by independent CDK and PCNA binding domains in p21Cip1. Nature 375, 159-161.

Levy, Y.S., Merims, D., Panet, H., Barhum, Y., Melamed, E., Offen, D., 2003. Induction of neuron-specific enolase promoter and neuronal markers in differentiated mouse bone marrow stromal cells. J. Mol. Neurosci. 21, 121-132.

Maitra, B., Szekely, E., Gjini, K., Laughlin, M.J., Dennis, J., Haynesworth, S.E., Koc O.N., 2004. Human mesenchymal stem cells support unrelated donor hematopoietic stem cells and suppress T-cell activation. Bone Marrow Transplant. 33, 597-604.

Mahmood, A., Lu, D., Wang, L., Chopp, M., 2002. Intracerebral transplantation of marrow stromal cells cultured with neurotrophic factors promotes functional recovery in adult rats subjected to traumatic brain injury. J. Neurotrauma 19 , 1609-1617.

Mudo, G., Bonomo, A., Di Liberto, V., Frinchi, M., Fuxe, K., Belluardo, N., 2009. The FGF-2/FGFRs neurotrophic system promotes neurogenesis in the adult brain. J. Neural Transm.

Masui, S., Nakatake, Y., Toyooka, Y., Shimosato, D., Yagi, R., Takahashi, K., Okochi, H., Okuda, A., Matoba, R., Sharov, A.A., Ko, M.S., Niwa, H., 2007. Pluripotency governed by Sox2 via regulation of Oct3/4 expression in mouse embryonic stem cells. Nat. Cell Biol. 9, 625-635.

Moskowitz, P.F., Oblinger, M.M., 1995. Transcriptional and post-transcriptional mechanisms regulating neurofilament and tubulin gene expression during normal development of the rat brain. Brain Res. Mol. Brain Res. 30, 211-222.

Marshall, O.J., Harley, V.R., 2000. Molecular mechanisms of SOX9 action. Mol. Genet. Metab. 71, 455-462.

Nasef, A., Mathieu, N., Chapel, A., Frick, J., Francois, S., Mazurier, C., Boutarfa, A., Bouchet, S., Gorin, N.C., Thierry, D., Fouillard, L., 2007. Immunosuppressive effects of mesenchymal stem cells: involvement of HLA-G. Transplantation 84, 231-237.

Okabe, S. Forsberg-Nilsson, K., Spiro, A.C., Segal, M., McKay, R.D., 1996 Development of neuronal precursor cells and functional postmitotic neurons from embryonic stem cells in vitro. Mech. Dev. 59, 89-102.

Pacary, E., Legros, H., Valable, S., Duchatelle, P., Lecocq, M., Petit, E., Nicole, O. Bernaudin, M., 2006. Synergistic effects of $\mathrm{CoCl}(2)$ and ROCK inhibition on mesenchymal stem cell differentiation into neuron-like cells. J. Cell Sci. 119, 2667-2678.

Pelletier, M., Oliver, L., Meflah, K., Vallette, F.M., 2005. Caspase-3 can be pseudoactivated by a $\mathrm{Ca} 2+$-dependent proteolysis at a non-canonical site. FEBS Lett. 579, 2364-2368

Ross, J.J., Verfaillie, C.M., 2008. Evaluation of neural plasticity in adult stem cells. Philos. Trans. R. Soc. London B: Biol. Sci. 363, 199-205.

Rosova, I., Dao, M., Capoccia, B., Link, D., Nolta, J.A., 2008. Hypoxic preconditioning results in increased motility and improved therapeutic potential of human mesenchymal stem cells. Stem Cells 26, 2173-2182.

Reynolds, B.A., Tetzlaff, W., Weiss, S., 1992. A multipotent EGF-responsive striatal embryonic progenitor cell produces neurons and astrocytes. J. Neurosci. 12, 4565-4574.
Reichardt, L.F., 2006. Neurotrophin-regulated signalling pathways. Philos. Trans. R. Soc. London B: Biol. Sci. 361, 1545-1564.

Roth, A.D., Leisewitz, A.V., Jung, J.E., Cassina, P., Barbeito, L., Inestrosa, N.C., Bronfman, M., 2003. PPAR gamma activators induce growth arrest and process extension in B12 oligodendrocyte-like cells and terminal differentiation of cultured oligodendrocytes. J. Neurosci. Res. 72, 425-435.

Rowitch, D.H., Lu, Q.R., Kessaris, N., Richardson, W.D., 2002. An 'oligarchy' rules neural development. Trends Neurosci. 25, 417-422.

Song, S., Sanchez-Ramos, J., 2003. Brain as the sea of marrow. Exp. Neurol. 184, 54-60.

Sykova, E., Jendelova, P., 2007. In vivo tracking of stem cells in brain and spinal cord injury. Prog. Brain Res. 161, 367-383.

Schwarz, J., 2007. Developmental perspectives on human midbrain-derived neural stem cells. Parkinsonism Relat. Disord. 13 (3), S466-468.

Song, S., Song, S., Zhang, H., Cuevas, J., Sanchez-Ramos, J., 2007. Comparison of neuron-like cells derived from bone marrow stem cells to those differentiated from adult brain neural stem cells. Stem Cells Dev. 16, 747-756.

Shiota, M., Heike, T., Haruyama, M., Baba, S., Tsuchiya, A., Fujino, H., Kobayashi, H., Kato, T., Umeda, K., Yoshimoto, M., Nakahata, T., 2007. Isolation and characterization of bone marrow-derived mesenchymal progenitor cells with myogenic and neuronal properties. Exp. Cell Res. 313, 1008-1023.

Seoane, J., Le, H.V., Massague, J., 2002. Myc suppression of the p21(Cip1) Cdk inhibitor influences the outcome of the p53 response to DNA damage. Nature 419, 729-734.

Sanchez-Ramos, J., Song, S., Cardozo-Pelaez, F., Hazzi, C., Stedeford, T., Willing, A., Freeman, T.B., Saporta, S., Janssen, W., Patel, N., Cooper, D.R., Sanberg, P.R., 2000. Adult bone marrow stromal cells differentiate into neural cells in vitro. Exp. Neurol. 164, 247-256.

Tatard, V.M., D'Ippolito, G., Diabira, S., Valeyev, A., Hackman, J., McCarthy, M., Bouckenooghe, T., Menei, P., Montero-Menei, C.N., Schiller, P.C., 2007. Neurotrophin-directed differentiation of human adult marrow stromal cells to dopaminergic-like neurons. Bone 40, 360-373.

Tsai, R.Y., Kim, S., 2005. Fibroblast growth factor 2 negatively regulates the induction of neuronal progenitors from neural stem cells. J. Neurosci. Res. 82, 149-159.

Temple, S., 2001. The development of neural stem cells. Nature 414, 112-117.

Tondreau, T., Lagneaux, L., Dejeneffe, M., Massy, M., Mortier, C., Delforge, A., Bron, D., 2004. Bone marrow-derived mesenchymal stem cells already express specific neural proteins before any differentiation. Differentiation 72, 319-326.

Tao, H., Rao, R., Ma, D.D., 2005. Cytokine-induced stable neuronal differentiation of human bone marrow mesenchymal stem cells in a serum/feeder cell-free condition. Dev. Growth Differ. 47, 423-433.

Vandesompele, J., De Preter, K., Pattyn, F., Poppe, B., Van Roy, N., De Paepe, A. Speleman, F., 2002. Accurate normalization of real-time quantitative RT-PCR data by geometric averaging of multiple internal control genes. Genome Biol. 3 RESEARCH0034.

Vergano-Vera, E., Mendez-Gomez, H.R., Hurtado-Chong, A, Cigudosa, J.C., VicarioAbejon, C., 2009. FGF-2 increases the expression of neurogenic genes and promotes the migration and differentiation of neurons derived from transplanted neural stem/progenitor cells. Neuroscience.

Woodbury, D., Reynolds, K., Black, I.B., 2002. Adult bone marrow stromal stem cells express germline, ectodermal, endodermal, and mesodermal genes prior to neurogenesis. J. Neurosci. Res. 69, 908-917.

Wislet-Gendebien, S., Leprince, P., Moonen, G., Rogister, B., 2003. Regulation of neural markers nestin and GFAP expression by cultivated bone marrow stromal cells. J. Cell Sci. 116, 3295-3302.

Wada, K., Nakajima, A., Katayama, K., Kudo, C., Shibuya, A., Kubota, N., Terauchi, Y., Tachibana, M., Miyoshi, H., Kamisaki, Y., Mayumi, T., Kadowaki, T., Blumberg, R.S., 2006. Peroxisome proliferator-activated receptor gamma-mediated regulation of neural stem cell proliferation and differentiation. J. Biol. Chem. $281,12673-12681$.

Wang, S., Sdrulla, A.D., diSibio, G., Bush, G., Nofziger, D., Hicks, C., Weinmaster, G., Barres, B.A., 1998. Notch receptor activation inhibits oligodendrocyte differentiation. Neuron 21, 63-75.

Yang, Q., Mu, J., Li, Q., Li, A., Zeng, Z., Yang, J., Zhang, X., Tang, J., Xie, P., 2008. A simple and efficient method for deriving neurospheres from bone marrow stromal cells. Biochem. Biophys. Res. Commun. 372, 520-524.

Zhao, L.R., Duan, W.M., Reyes, M., Keene, C.D., Verfaillie, C.M., Low, W.C., 2002. Human bone marrow stem cells exhibit neural phenotypes and ameliorate neurological deficits after grafting into the ischemic brain of rats. Exp. Neurol. $174,11-20$.

Zhang, J., Li, Y., Chen, J., Cui, Y., Lu, M., Elias, S.B., Mitchell, J.B., Hammill, L., Vanguri, P., Chopp, M., 2005. Human bone marrow stromal cell treatment improves neurological functional recovery in EAE mice. Exp. Neurol. 195, 16-26.

Zimmerman, L., Parr, B., Lendahl, U., Cunningham, M., McKay, R., Gavin, B., Mann, J. Vassileva, G., McMahon, A., 1994. Independent regulatory elements in the nestin gene direct transgene expression to neural stem cells or muscle precursors. Neuron 12, 11-24. 